1 Concentration effect on equilibrium fractionation of

2 Mg-Ca isotopes in carbonate minerals: insights from

3

4

5

6

7

8 China

$9 \quad{ }^{b}$ Mengcheng National Geophysical Observatory, Anhui, China

10

11

12

13

14

15

16

Wenzhong Wang ${ }^{\mathrm{a}, \mathrm{b}}$, Tian Qin ${ }^{\mathrm{a}, \mathrm{b}}$, Chen Zhou ${ }^{\mathrm{c}}$, Shichun Huang ${ }^{\mathrm{d}}$,

Zhongqing $\mathrm{Wu}^{\mathrm{a}, \mathrm{b},{ }^{*}}$, Fang Huang ${ }^{\mathrm{c}, *}$ 230026, China States

4122 words, 8 Figures, 3 Tables, supplementary materials

\title{
first-principles calculations
}

${ }^{a}$ Laboratory of Seismology and Physics of Earth's Interior, School of Earth and Space

Sciences, University of Science and Technology of China, Hefei, Anhui 230026,

${ }^{\mathrm{c}}$ CAS Key Laboratory of Crust-Mantle Materials and Environments, School of Earth and Space Sciences, University of Science and Technology of China, Hefei, Anhui

${ }^{\mathrm{d}}$ Department of Geoscience, University of Nevada, Las Vegas, NV 89154, United

* Correspondences and requests for materials should be addressed to Z.-Q. Wu (wuzq10@ustc.edu.cn) or F. Huang (fhuang@ustc.edu.cn)

1 


\section{Abstract}

Naturally occurring carbonates have a wide variation in $\mathrm{Mg}$ and $\mathrm{Ca}$ contents. Using the density-functional-theory calculations, this study examines the effect of $\mathrm{Mg}$ and $\mathrm{Ca}$ concentrations on bond lengths and equilibrium fractionation factors of $\mathrm{Mg}$-Ca isotopes among calcite-type carbonate minerals $\left(\mathrm{Mg}_{x} \mathrm{Ca}_{1-x} \mathrm{CO}_{3}\right) \cdot \mathrm{Mg}$ content $x$ and $\mathrm{Ca}$ content $(1-x)$ of the investigated carbonate minerals range from $1 / 12$ to 1 and from $1 / 36$ to 1 , respectively. Concentration of $\mathrm{Ca}$ and $\mathrm{Mg}$ in carbonates have significant effects on $\mathrm{Ca}-\mathrm{O}$ and $\mathrm{Mg}-\mathrm{O}$ bond lengths when $x$ is close to $0,0.5$ or 1 . Because equilibrium isotope fractionation factors $\left(10^{3} \ln \alpha\right)$ are mainly controlled by their relevant bond strengths, which can be measured using their average bond lengths, $10^{3} \ln \alpha$ of ${ }^{26} \mathrm{Mg} /{ }^{24} \mathrm{Mg}$ and ${ }^{44} \mathrm{Ca} /{ }^{40} \mathrm{Ca}$ between calcite-type carbonate minerals and dolomite also vary dramatically with $\mathrm{Mg}$ content, especially when $x$ is close to 0 and 1 . For instance, at $300 \mathrm{~K}, 10^{3} \ln \alpha$ of ${ }^{26} \mathrm{Mg} /{ }^{24} \mathrm{Mg}$ between $\mathrm{Mg}_{1 / 12} \mathrm{Ca}_{11 / 12} \mathrm{CO}_{3}$ and dolomite $(x=0.5)$ is $\sim-4.3 \%$, while $10^{3} \ln \alpha$ of ${ }^{44} \mathrm{Ca} /{ }^{40} \mathrm{Ca}$ between $\mathrm{Mg}_{23 / 24} \mathrm{Ca}_{1 / 24} \mathrm{CO}_{3}$ and dolomite is $\sim 6 \%$. Dolomite is enriched in ${ }^{26} \mathrm{Mg}$ but depleted in ${ }^{44} \mathrm{Ca}$ relative to all other carbonate minerals, which is consistent with it having the shortest $\mathrm{Mg}-\mathrm{O}$ bond length and the longest $\mathrm{Ca}-\mathrm{O}$ bond lengths among all carbonates. At $300 \mathrm{~K}$, a small change of $x$ from 0.5 to 0.6 in dolomite could result in $1 \%$ variation in $10^{3} \ln \beta$ of ${ }^{26} \mathrm{Mg} /{ }^{24} \mathrm{Mg}$. Therefore, the concentration effect in carbonate minerals should be taken into account when applying the isotope fractionation factors of carbonate minerals to understand geochemical processes. 
Keywords: first-principle calculations, concentration effect, equilibrium fractionation, $\mathrm{Mg}-\mathrm{Ca}$ isotopes, carbonates

\section{Introduction} environmental and geochemical processes. Calcite, dolomite, and magnesite are the major carbonate minerals in sedimentary rocks. $\mathrm{C}, \mathrm{O}, \mathrm{Mg}$, and $\mathrm{Ca}$ stable isotopic compositions of these carbonates have a number of essential implications. For example, the oxygen isotopic compositions in carbonate minerals have been used as a thermometry investigating paleo-climate change (e.g., Bemis et al., 1998; Kim and O’Neil, 1997; Lea, 2014; McDermott, 2004). Carbon isotope excursions in marine carbonates and sedimentary organic matters are often related to catastrophic events in the Earth's history (e.g., Hoffman et al., 1998; Johnston et al., 2012; Kaufman and Knoll, 1995; Sahoo et al., 2012; Shields-Zhou and Och, 2011), and they are the key

51 parameters in the study of carbon cycling and paleo-climate changes (Werne and

52 Hollander, 2004; Ader et al., 2009; Meyer et al., 2013).

More recently, $\mathrm{Ca}$ isotopic compositions in marine carbonates have been used to constrain global Ca cycling (De La Rocha, 2000; Heuser et al., 2005; Farkaš et al.,

55 2007), and $\mathrm{Mg}$ isotope data in carbonates have been applied to constrain the oceanic cycling of Mg and continental weathering (Tipper et al., 2006b; Higgins and Schrag,

57 2010; Li et al., 2015). Furthermore, since $\mathrm{Mg}$ and $\mathrm{Ca}$ fluxes are usually coupled with 58 carbon cycles, $\mathrm{Mg}-\mathrm{Ca}$ isotopes have great potential to trace deep carbon recycling 
59 (DePaolo, 2004; Huang et al., 2011; Yang et al., 2012; Zhang and Li, 2012; Cheng et

60 al., 2015; Huang et al., 2015; Liu et al., 2015). Reported $\delta^{26 / 24} M g$ values of

61 precipitated marine carbonates vary from around $-5 \%$ to $-1 \%$ in magnesian calcites

62 (Galy et al., 2002; de Villiers et al., 2005; Tipper et al., 2006a; Tipper et al., 2006b;

63 Buhl et al., 2007; Hippler et al., 2009), and from -2\%o to -1\%o in dolomites (Galy et

64 al., 2002; Chang et al., 2003; Jacobson et al., 2010). It is not clear whether the

$65 \delta^{26 / 24} M g$ variations in carbonate minerals reflect different precipitation

66 environments or $\mathrm{Mg}$ isotopic fractionation among $\mathrm{Mg}$-bearing species. Therefore, in

67 order to better apply stable isotope data into geochemical studies, it is critical to

68 understand equilibrium isotope fractionation factors among carbonate minerals.

69 Chemical compositions of carbonate minerals vary tremendously as solid

70 solutions due to the incorporations of divalent cations including $\mathrm{Mg}^{2+}, \mathrm{Sr}^{2+}, \mathrm{Ba}^{2+}$, and

$71 \mathrm{Cd}^{2+}$ (Tesoriero and Pankow, 1996; Huang and Fairchild, 2001). Generally, $\mathrm{Mg}^{2+}$

72 cations could substitute $\mathrm{Ca}^{2+}$ cations to form low-Mg calcite (with $<4 \mathrm{~mol} \% \mathrm{Mg}$,

73 mole ratio hereafter defined as $\mathrm{Mg} /(\mathrm{Mg}+\mathrm{Ca})$ ) and high- $\mathrm{Mg}$ calcite (with $>4 \mathrm{~mol} \%$

$74 \mathrm{Mg}$ ). The $\mathrm{Mg}$ content of experimentally synthesized calcites in aqueous solutions

75 could be up to 22 mol\% (Mucci and Morse, 1983; Mucci, 1986; Huang and Fairchild,

76 2001; Meldrum and Hyde, 2001; Li et al., 2012), but magnesites with low Ca content

77 were rarely reported in literature. Although naturally occurring dolomites generally

78 contain $50 \mathrm{~mol} \% \mathrm{MgCO}_{3}$ in an idealized mineral structure, they also show variable

$79 \mathrm{Mg}$ contents (about 40-50 mol\%) (Drits et al., 2005). 
81 further impacts the equilibrium isotope fractionation factors among minerals. For 82 example, based on first-principles calculations, Feng et al. (2014) reported that 83 equilibrium $\mathrm{Ca}$ isotope fractionation factors between clinopyroxene (cpx) and 84 orthopyroxene (opx) are controlled not only by temperature, but also the Ca content in 85 opx. Pinilla et al. (2015) reported the noticeable equilibrium Mg isotopes fractionation between $\mathrm{Mg}$-calcites with $\mathrm{Mg}$ contents of $3.12 \mathrm{~mol} \%$ and $6.25 \mathrm{~mol} \%$. However, their calculations were conducted with the fixed cell parameters, which means that these two investigated $\mathrm{Mg}$-calcites may not be under the same pressure and thus they are not in thermodynamic equilibrium. It is therefore important to scrutinize the possible concentration effect on stable isotope fractionation among carbonate minerals. It is challenging to synthesize carbonate minerals with a wide range of controllable $\mathrm{Mg}$ contents at ambient conditions through inorganic experiments, and 93 synthesis of dolomite is even referred to as the "dolomite problem" for decades 94 (Zenger et al., 1980; Land, 1998; Warren, 2000). Therefore, experimental 95 determination of the equilibrium isotopes fractionation between carbonate minerals 96 with variable chemical compositions remains a great challenge. No experimental 97 study has yet been reported to examine the concentration effect on the equilibrium 98 isotope fractionation between carbonate minerals. $\mathrm{Mg}$ isotope fractionation factors 99 between carbonate minerals ( $\mathrm{Mg}$-calcite and dolomite) and aqueous $\mathrm{Mg}$ solutions were experimentally measured at various temperatures (Pearce et al., 2012; Li et al., 
2012; Saulnier et al., 2012; Mavromatis et al., 2013; Li et al., 2015) and theoretically calculated (Rustad et al., 2010; Schauble, 2011), but there is a significant discrepancy between experimental and theoretical results. This highlights the complexity of determining isotope fractionation factors, such as kinetic effect (Saenger and Wang, 2014). The Mg concentration variations in synthesized carbonate minerals may also contribute to the complexity.

Recent advances in computational capabilities prove that the density functional theory (DFT) provides a powerful tool to calculate equilibrium isotope fractionation factors. DFT calculations, which show comparable precision relative to the well-designed experiments (Lejaeghere et al., 2016), have been widely used to calculate equilibrium fractionation factors for a number of systems such as $\mathrm{Mg}, \mathrm{Si}, \mathrm{Ca}$, and V (Schauble et al., 2004; Griffith et al., 2008; Méheut et al., 2009; Schauble, 2011; Li and Liu, 2011; Kowalski and Jahn, 2011; Kowalski et al., 2013; Huang et al., 2013; Huang et al., 2014; Feng et al., 2014; Wu et al., 2015). Natural calcite and magnesite are solid solutions with substantial variations in $\mathrm{Ca}-\mathrm{Mg}$ concentration. For better understanding the concentration effect on equilibrium isotope fractionation, we estimate fractionation factors of $\mathrm{Mg}$ and $\mathrm{Ca}$ isotopes among carbonate minerals $\left(\mathrm{Mg}_{x} \mathrm{Ca}_{1-x} \mathrm{CO}_{3}\right)$ with $x$ varying from 0 to 1 using the DFT calculations. We focus on the effect of $\mathrm{Ca}-\mathrm{Mg}$ substitutions on carbonate mineral structures, $\mathrm{Ca}-\mathrm{O}$ and $\mathrm{Mg}-\mathrm{O}$ bonding, and equilibrium isotope fractionation. Our results reveal a significant concentration effect on equilibrium fractionation of $\mathrm{Mg}-\mathrm{Ca}$ isotopes in carbonate 
minerals.

123

124

125

126

127

128

132

133

134

135

137 138 Kelvin, and $\omega_{\text {ih or il }}$ is the vibrational frequency of the $i^{\text {th }}$ mode. Following Richet et 139 al. (1977), the equilibrium isotope fractionation between two Phases A and B can be 140 rewritten in per mil as:

141

\section{Calculation methods}

Equilibrium isotope fractionation arises from changes in vibrational frequencies caused by isotopic substitution of an interested element in two phases (Bigeleisen and Mayer, 1947; Urey, 1947). The isotope fractionation factor of element X between two phases $\mathrm{A}$ and $\mathrm{B}, \alpha_{A-B}$, is the ratio of their isotope ratios of these two phases under equilibrium. According to Richet et al. (1977), the isotope fractionation factor between Phase A and an ideal gas of $\mathrm{X}$ atoms is the reduced partition function ratio $\beta_{A}$ of the Element $\mathrm{X}$, defined in the harmonic approximation as:

$$
\beta_{A}=\frac{Q_{h}}{Q_{l}}=\prod_{i}^{3 N} \frac{u_{i h}}{u_{i l}} \frac{e^{-\frac{1}{2} u_{i h}}}{1-e^{-u_{i h}}} \frac{1-e^{-u_{i l}}}{e^{-\frac{1}{2} u_{i l}}}
$$

where $Q$ is the vibrational partition function, index $h$ and $l$ refer to the heavy and light isotopes, respectively; $i$ is a running index of vibrational frequency mode, and $N$ is the number of atoms in the unit cell. A crystal with $\mathrm{N}$ atoms has $3 N$ vibrational modes and the product runs over all $3 N$ phonon modes. $u_{i h}$ and $u_{i l}$ are defined as:

$$
u_{i h o r i l}=h \omega_{i h o r i l} / k_{B} T
$$

where $h$ is the Planck constant, $k_{B}$ is the Boltzmann constant, $T$ is temperature in

$$
\Delta_{A-B}=10^{3} \ln \alpha_{A-B}=10^{3} \ln \beta_{A}-10^{3} \ln \beta_{B}
$$


142 The calculation details in this study are similar to that published in previous work

143 (Schauble, 2011; Li and Liu, 2011; Huang et al., 2013; Huang et al., 2014; Feng et al.,

144 2014; Wu et al., 2015). All calculations were performed using an open-source

145 software "Quantum Espresso" based on the DFT, plane wave, and pseudopotential

146 (Giannozzi et al., 2009). Electronic wave functions are expanded by a plane-wave

147 basis set. The interaction between the valence electrons and the ionic core is described

148 using pseudopotential. Local density approximation (LDA) for exchange correlation

149 functional (Perdew and Zunger, 1981) was used in this study because of its

150 advantages on calculating mineral structures and thermodynamic properties of

151 minerals (Wentzcovitch et al., 2010; Huang et al., 2013). The plane-wave cutoff

152 energy is 70 Ry.

153 The pseudopotentials of calcium and carbon were generated using Vanderbilt

154 method (Vanderbilt, 1990) with a configuration of $3 \mathrm{~s}^{2} 3 \mathrm{p}^{6} 4 \mathrm{~s}^{1}$ and a 1.85 Bohr cutoff

155 radius for calcium, and a configuration of $2 \mathrm{~s}^{2} 2 \mathrm{p}^{2}$ and a 1.3 Bohr cutoff radius for

156 carbon. The pseudopotential of magnesium was generated using the method of von

157 Barth and Car for all channels using a 2.5 Bohr cutoff radius and five configurations,

$1583 s^{2} 3 p^{0}, 3 s^{1} 3 p^{1}, 3 s^{1} 3 p^{0.5} 3 d^{0.5}, 3 s^{1} 3 p^{0.5}, 3 s^{1} 3 d^{1}$, with weights of $1.5,0.6,0.3,0.3,0.2$,

159 respectively. The oxygen pseudopotential was generated by the method of Troullier

160 and Martins (1991) with configuration $2 \mathrm{~s}^{2} 2 \mathrm{p}^{4}$ and a cutoff radius of 1.45 Bohr.

161 Brillouin zone integrations over electronic states were performed with $N_{1} \times N_{2} \times N_{3}$

162 k-point grid dependent on the size of unit cells (see Table S1). 
166 (Wentzcovitch, 1991) and the residual forces converge within $10^{-4} \mathrm{Ry} / \mathrm{Bohr}$. The

167 dynamical matrices were calculated on a regular q mesh dependent on the size of unit

168 cells (Table S1) using the density-functional perturbation theory (DFPT) and then 169 interpolated on a dense $q$ mesh to obtain the vibrational density of the state of 170 minerals.

\section{3. Results}

\section{$172 \quad 3.1$ Relaxed crystal structures}

173 The unit structure cell of calcite with space group R-3c contains six 174 symmetry-equivalent Ca atoms (Graf, 1961; Markgraf and Reeder, 1985). All initial 175 carbonate structures before optimization, with $\mathrm{Mg} /(\mathrm{Mg}+\mathrm{Ca})$ (mole ratio hereafter)

176 varying from $1 / 12$ to 1 , were obtained by replacing $\mathrm{Ca}$ atoms with $\mathrm{Mg}$ atoms in the

177 primitive calcite cell. For instance, one of the $12 \mathrm{Ca}$ atoms in a 60 -atom cell of calcite

178 was substituted by one $\mathrm{Mg}$ atom to make a $\mathrm{Mg} /(\mathrm{Mg}+\mathrm{Ca})$ of $1 / 12$. Because the initial 179 carbonate structures with $\mathrm{Mg} /(\mathrm{Mg}+\mathrm{Ca})$ of $2 / 6,3 / 6$, and 4/6 have more than one 180 configurations, all nonequivalent configurations in a 30-atom cell were calculated and

181 the configurations with the lowest total energy were selected for dynamical matrices 182 calculations. To test the effect of the supercell size, we also consider the structure with $183 \mathrm{Mg} /(\mathrm{Mg}+\mathrm{Ca})$ of $2 / 12$ in a 60 -atom supercell, which is twice as large as that with 

energy among all nonequivalent configurations was selected as for dynamical matrices calculations. The optimized crystal structures of carbonates with variable

$187 \mathrm{Mg} /(\mathrm{Mg}+\mathrm{Ca})$ are shown in Fig. 1 with emphasis on $\mathrm{Mg}-\mathrm{O}$ and $\mathrm{Ca}-\mathrm{O}$ polyhedrons.

188 Although the initial structures of carbonates with $\mathrm{Mg} /(\mathrm{Mg}+\mathrm{Ca})$ of $3 / 6$ and 1 are 189 calcite-type structures, their optimized structures are consistent with dolomite and 190 magnesite structures, respectively, as indicated by the fractional coordinates shown in 191 Table S2. Both $\mathrm{Ca}$ and $\mathrm{Mg}$ have a coordination number $(\mathrm{CN})$ of six in all calcite-type 192 carbonates with variable $\mathrm{Mg} /(\mathrm{Mg}+\mathrm{Ca})$, while $\mathrm{Ca}$ is nine-fold coordinated in aragonite.

193 The calculated crystal lattice parameters of all carbonate minerals (Table S3), are 194 consistent with experimental results within 1\% (Fig. 2) after considering the 195 temperature effect estimated using the volume expansion of calcite from static 196 condition to $300 \mathrm{~K}$, in which the volume of calcite increases by $1.8 \%$. After the 197 temperature correction, the crystal volumes are consistent with experimental data 198 within $1 \%$, indicating that the predicted crystal volumes in this study are reliable. The 199 calculated vibrational frequencies of calcite, dolomite, magnesite, and aragonite agree 200 well with experimental results (Fig. 3 and Table S4), with the slope between 201 calculated frequencies and measured frequencies being $0.998 \pm 0.020\left(1 \sigma, \mathrm{R}^{2}=0.9998\right)$ 202 (Fig. 3 and Table S4). This demonstrates that the calculated equilibrium isotope 203 fractionation factors are reliable and accurate. Therefore, the LDA is a good exchange 204 correlation functional for calculations of isotope fractionation among minerals, as 
205 demonstrated by previous studies (e.g., Li et al., 2011; Huang et al., 2013; Feng et al., 206 2014; Wu et al., 2015). Based on the analysis in previous work (Méheut et al., 2009), 207 a deviation of $\mathrm{n} \%$ on phonon frequencies would induce an error of $\mathrm{n} \%$ at low 208 temperature and $2 \mathrm{n} \%$ at high temperature on $10^{3} \ln \beta$. Therefore, the relative 209 uncertainties of our calculated $10^{3} \ln \beta$ and $10^{3} \ln \alpha$ are estimated at about $4 \%$ and $2106 \%$, respectively, under investigated temperature intervals (Méheut et al., 2009; 211 Kowalski et al., 2013; Feng et al., 2014).

\subsection{Average $\mathrm{Mg}-\mathrm{O}$ and $\mathrm{Ca}-\mathrm{O}$ bond lengths in carbonates}

Average $\mathrm{Mg}-\mathrm{O}$ and $\mathrm{Ca}-\mathrm{O}$ bond lengths in carbonate minerals with variable $\mathrm{Mg} /(\mathrm{Mg}+\mathrm{Ca})$ at static condition are reported in Table 1 and Fig. 4. As shown in Fig. 4, average $\mathrm{Mg}-\mathrm{O}$ and $\mathrm{Ca}-\mathrm{O}$ bond lengths vary with $\mathrm{Mg} /(\mathrm{Mg}+\mathrm{Ca})$ of carbonate minerals. Our results show that average $\mathrm{Mg}-\mathrm{O}$ and $\mathrm{Ca}-\mathrm{O}$ bond lengths of the carbonate mineral with $\mathrm{Mg} /(\mathrm{Mg}+\mathrm{Ca})$ of $1 / 6$ calculated from the 60 -atom supercell are consistent to those

218 obtained from the 30-atom system. Dolomite has the shortest average $\mathrm{Mg}-\mathrm{O}$ bond

219 length and the longest average $\mathrm{Ca}-\mathrm{O}$ bond length among all calculated carbonate 220 minerals (Fig. 4a and 4b). Because the size of $\mathrm{Ca}^{2+}$ is larger than $\mathrm{Mg}^{2+}$ in carbonates,

221 we expect that the $\mathrm{Mg}-\mathrm{O}$ bond in calcite is longer than that in magnesite. Therefore, 222 the average $\mathrm{Mg}-\mathrm{O}$ bond length increases in the order of dolomite < magnesite < 223 calcite. For the same taken, when $\mathrm{Ca}$ occupies the small $\mathrm{Mg}$ site in magnesite, $\mathrm{Ca}-\mathrm{O}$

224 bond in magnesite is shorter than the one in calcite and thus the sequence of average $225 \mathrm{Ca}-\mathrm{O}$ bond length is dolomite $>$ calcite $>$ magnesite. The predicted differences of 
227 length between dolomite and calcite from our calculations are $-0.019 \AA$ and $0.02 \AA$

228 respectively (Table 1), which are consistent with the results from previous

229 experimental and theoretical studies (Markgraf and Reeder, 1985; Reeder and

230 Markgraf, 1986; Schauble, 2011). Finally, aragonite has an average Ca-O bond length

231 much larger than calcite-type carbonate minerals (Table 1).

\section{$232 \quad 3.3$ Isotope fractionation factors}

233 The calculated reduced partition function ratios of ${ }^{26} \mathrm{Mg} /{ }^{24} \mathrm{Mg}\left(10^{3} \ln \beta^{26}{ }_{\mathrm{Mg}}{ }^{24} \mathrm{Mg}\right)$ 234 and ${ }^{44} \mathrm{Ca} /{ }^{40} \mathrm{Ca}\left(10^{3} \ln \beta_{44} \mathrm{Ca}^{40} \mathrm{Ca}\right)$ are shown in Fig. 5. The polynomial fitting 235 parameters are reported in Table $2.10^{3} \ln \alpha_{\text {minerals-dolomite }}$ (equilibrium isotope 236 fractionation factors between $\mathrm{Mg}_{x} \mathrm{Ca}_{1-x} \mathrm{CO}_{3}$ and dolomite) of ${ }^{26} \mathrm{Mg} /{ }^{24} \mathrm{Mg}$ and $237{ }^{44} \mathrm{Ca} /{ }^{40} \mathrm{Ca}$ are plotted as a function of temperature in Fig. 6. Relative polynomial 238 fitting parameters are given in Table 3. Small differences between results of 239 calcite-type carbonate minerals with $\mathrm{Mg} /(\mathrm{Mg}+\mathrm{Ca})$ of $1 / 6$ and 2/12 indicate that the 240 effect of supercell size secondary and negligible. $10^{3} \ln \beta^{26} \mathrm{Mg}-{ }^{24} \mathrm{Mg}$ increases in the 241 order of $\mathrm{Mg}$-calcite $\left(\mathrm{Mg}_{1 / 12} \mathrm{Ca}_{11 / 12} \mathrm{CO}_{3}\right)<$ magnesite < dolomite, which is generally 242 consistent with previous theoretical results (Rustad et al., 2010; Schauble, 2011), as 243 well as experimental and natural observations (Li et al., 2012; Saulnier et al., 2012;

244 Mavromatis et al., 2013; Saenger and Wang, 2014; Li et al., 2015). As expected from 245 the compositional dependence of average bond lengths on $\mathrm{Mg} /(\mathrm{Mg}+\mathrm{Ca})$, $24610^{3} \ln \beta^{26} \mathrm{Mg}^{24} \mathrm{Mg}$ and $10^{3} \ln \beta^{44} \mathrm{Ca}-{ }^{40} \mathrm{Ca}$ of calcite-type carbonate minerals vary 
247 significantly with $\mathrm{Mg} /(\mathrm{Mg}+\mathrm{Ca})$ (Fig. 5-7). The more sensitive the bond lengths to $248 \mathrm{Mg} /(\mathrm{Mg}+\mathrm{Ca})$, the more rapidly the reduced partition function ratios change with $249 \mathrm{Mg} /(\mathrm{Mg}+\mathrm{Ca})$. The $10^{3} \ln \beta^{26}{ }_{M g}{ }^{24} \mathrm{Mg}$ of dolomite $(\mathrm{Mg} / \mathrm{Ca}=1)$ is always higher than 250 that of other calcite-type carbonate minerals with variable $\mathrm{Mg}$ proportions, while the $25110^{3} \ln \beta^{44} \mathrm{Ca}^{40} \mathrm{Ca}$ of dolomite is always lower than that of other calcite-type 252 carbonates and higher than that of aragonite (Fig. 6), consistent with the fact that 253 dolomite has the shortest $\mathrm{Mg}-\mathrm{O}$ and the longest $\mathrm{Ca}-\mathrm{O}$ bond length among all 254 carbonate minerals. Notably, isotope fractionation factors change dramatically with

$255 \mathrm{Mg} /(\mathrm{Mg}+\mathrm{Ca})$. For example, at $300 \mathrm{~K}, 10^{3} \ln \alpha$ of ${ }^{26} \mathrm{Mg} /{ }^{24} \mathrm{Mg}$ between calcites and 256 dolomite range from $-4.3 \%$ o to 0 and ${ }^{44} \mathrm{Ca} /{ }^{40} \mathrm{Ca}$ from 0 to $\sim 6 \%$ when $\mathrm{Mg} /(\mathrm{Mg}+\mathrm{Ca})$ 257 varies from $1 / 12$ to $1 / 2$. Therefore, in addition to temperature, $\mathrm{Mg} /(\mathrm{Mg}+\mathrm{Ca})$ in 258 carbonate minerals also significantly affects equilibrium isotope fractionation.

\section{4. Discussion}

\subsection{Concentration effect on average $\mathrm{Ca}-\mathrm{O}$ and $\mathrm{Mg}-\mathrm{O}$ bond lengths in carbonates}

$\mathrm{Ca}-\mathrm{O}$ and $\mathrm{Mg}-\mathrm{O}$ bond lengths in the carbonate minerals are also significantly affected by their Mg contents (Table 1 and Fig. 4), suggesting that the concentration effect on 265 bond length should be a ubiquitous phenomenon in minerals. When Element A replaces Element $\mathrm{B}$ with a different radius, Element $\mathrm{A}$ should be adapted to the 
269 A is low enough, the effect from Element B should be saturated and A-O bond lengths will be close to a constant. On the other hand, with increasing concentration of

271 Element A, average A-O bond length may gradually shift to a value similar to that of 272 an A-dominated mineral, in which case the effect of Element B is small. This explains 273 why average $\mathrm{Mg}-\mathrm{O}$ bond length decreases with increasing $\mathrm{Mg}$ content from 274 Mg-doped calcite to dolomite (Fig. 4a), and average $\mathrm{Ca}-\mathrm{O}$ bond length increases with increasing Ca content from Ca-doped magnesite to dolomite (Fig. 4b). from $1 / 2$ to $11 / 12, \mathrm{Mg}-\mathrm{O}$ bond length increases with increasing $\mathrm{Mg} /(\mathrm{Mg}+\mathrm{Ca})$ because

$278 \mathrm{Mg}$ atoms begin to occupy the larger Ca sites, resulting in much longer $\mathrm{Mg}-\mathrm{O}$ bonds 279 than the case in $\mathrm{Mg}$ sites. The average $\mathrm{Mg}$-O bond length increases as more $\mathrm{Mg}$ atoms occupy the large $\mathrm{Ca}$ sites. Similarly, when $\mathrm{Mg} /(\mathrm{Mg}+\mathrm{Ca})$ is less than $0.5, \mathrm{Ca}-\mathrm{O}$ bond

281 length decreases with decreasing $\mathrm{Mg} /(\mathrm{Mg}+\mathrm{Ca})$ because $\mathrm{Ca}$ atoms begin to occupy the 282 smaller $\mathrm{Mg}$ sites, resulting in much shorter $\mathrm{Ca}-\mathrm{O}$ bonds. This explains why average $283 \mathrm{Mg}-\mathrm{O}$ bond length increases when $\mathrm{Mg} /(\mathrm{Mg}+\mathrm{Ca})$ varies from 1/2 to 11/12 (Fig. 4a), 284 and average $\mathrm{Ca}-\mathrm{O}$ bond length decreases with increasing $\mathrm{Ca}$ content from dolomite to 285 Mg-doped calcite (Fig. 4b). As a consequence, dolomite has the shortest average $286 \mathrm{Mg}-\mathrm{O}$ and the longest average $\mathrm{Ca}-\mathrm{O}$ bond lengths among carbonate minerals (Fig. $4 \mathrm{a}$ 287 and $4 \mathrm{~b}$ ). This structure feature of carbonate minerals produces continuous variations 288 of the $\mathrm{Mg}-\mathrm{O}$ and $\mathrm{Ca}-\mathrm{O}$ bond lengths from calcite to magnesite. This is different from 
289 the case of opx where $\mathrm{Ca}-\mathrm{O}$ bond lengths vary with opx $\mathrm{Ca}$ concentration only when

290 it is low enough (Feng et al., 2014).

291

292

293

294

295

296

297

298

299

300

301

302

303

304

305

306

307

\subsection{Concentration effect on isotope fractionation factors}

The equilibrium fractionation factors of $\mathrm{Mg}$ and $\mathrm{Ca}$ isotopes between calcite-type carbonate minerals (calcite-magnesite series) and dolomite vary significantly with $\mathrm{Mg}$ content in carbonate minerals. They are correlated with the average bond lengths with slightly different slopes for carbonate minerals with $\mathrm{Mg} /(\mathrm{Mg}+\mathrm{Ca})<1 / 2$ and $\mathrm{Mg} /(\mathrm{Mg}+\mathrm{Ca})>1 / 2$ (Fig. 8), which likely reflects the different dependences of average bond lengths on $\mathrm{Mg} /(\mathrm{Mg}+\mathrm{Ca})$ due to the subtle disparity in structures between these two groups. When $\mathrm{Mg} /(\mathrm{Mg}+\mathrm{Ca})<1 / 2, \mathrm{Ca}$ atoms are dominant relative to $\mathrm{Mg}$ atoms and show the major effect on structures. Similarly, $\mathrm{Mg}$ shows the major effect in carbonates when $\mathrm{Mg} /(\mathrm{Mg}+\mathrm{Ca})>1 / 2$. Feng et al. (2014) also found that fractionation factors between opx and cpx are linearly correlated with average $\mathrm{Ca}-\mathrm{O}$ bond lengths in opx. Equilibrium isotope fractionations are controlled by relevant bond strengths (Bigeleisen and Mayer, 1947; Urey, 1947). As analyzed in previous studies (Urey, 1947; Schauble et al., 2004; Hill and Schauble, 2008; Young et al., 2009), shorter chemical bonds correspond to stronger bond strengths and higher vibrational frequencies, leading to enrichments in heavy isotopes relative to the longer and weaker chemical bonds. CN could also affect the bond strengths; however, the CNs of $\mathrm{Ca}$ and $\mathrm{Mg}$ in all calcite-type carbonates are six. Therefore, the bond lengths in calcite-type carbonate minerals dominantly control their bond strengths, resulting in a 
310 linear correlation between the inter-mineral isotope fractionations and the average

311 bond lengths of carbonate minerals. This is similar to the case in opx and cpx where

$312 \mathrm{Ca}$ is six-fold coordinated, and $\mathrm{Ca}$ isotopic fractionation between opx and cpx is also

313 linearly correlated with Ca-O bond length in opx (Feng et al., 2014).

314 Pinilla et al. (2015) recently calculated equilibrium $\mathrm{Mg}$ isotopes fractionation

315 factor between Mg-calcites with different $\mathrm{Mg}$ contents using the DFT method and

316 they found that the calcite-type carbonate mineral with lesser $\mathrm{Mg}(3.12 \mathrm{~mol} \%)$ is

317 enriched in heavy $\mathrm{Mg}$ isotopes relative to the one with more $\mathrm{Mg}$ (6.25 mol\%), which

318 is in contrast with the expectation from this study that considers the carbonate

319 minerals with $\mathrm{Mg}$ content higher than $6.25 \mathrm{~mol} \%$. The discrepancy probably arises

320 from the difference in the calculation method. In their calculations, the cell parameters

321 of carbonate minerals are fixed. Therefore, carbonate mineral with $3.12 \mathrm{~mol} \% \mathrm{Mg}$

322 must be under a higher pressure than the one with 6.25 mol\% given that $\mathrm{Mg}$ atom is

323 much smaller than $\mathrm{Ca}$ atom. Because increase of pressure can dramatically increase

$32410^{3} \ln \beta$ (Huang et al., 2013; Huang et al., 2014; Wu et al., 2015), this impractical

325 pressure difference probably significantly increases $10^{3} \ln \beta$ of ${ }^{26} \mathrm{Mg} /{ }^{24} \mathrm{Mg}$ of the

326 carbonate mineral with $3.12 \mathrm{~mol} \% \mathrm{Mg}$ relative to the one with $6.25 \mathrm{~mol} \% \mathrm{Mg}$.

\section{$327 \quad 4.3$ Implications for $\mathrm{Mg}$ and $\mathrm{Ca}$ isotopic compositions of carbonates}

328 Stable isotopic compositions of carbonates provide important records on many

329 low temperature geochemical processes. Their isotopic compositions are

330 indispensable for understanding these processes. $\delta^{26 / 24} \mathrm{Mg}$ values of precipitated 
331 marine Mg-calcites vary from -5\%o to -1\%o (Galy et al., 2002; de Villiers et al., 2005;

332 Tipper et al., 2006a; Tipper et al., 2006b; Buhl et al., 2007; Hippler et al., 2009) and

$333 \delta^{26 / 24} \mathrm{Mg}$ values of dolomites range from about $-2 \%$ to $-1 \%$ (Galy et al., 2002;

334 Chang et al., 2003; Jacobson et al., 2010). These $\delta^{26 / 24} \mathrm{Mg}$ variations of Mg-calcite

$335(\sim 4 \%)$ and dolomite $(\sim 1 \%)$ are ascribed to kinetic effects (Immenhauser et al., 2010$)$

336 or unconfirmed "vital effects" (Chang et al., 2004). According to our calculated results,

337 although kinetic effects are potentially important, the concentration effect on $\mathrm{Mg}$ and

$338 \mathrm{Ca}$ isotope fractionation should be also considered. The variation of $10^{3} \ln \alpha$ of $\mathrm{Mg}$

339 isotopes between $\mathrm{Mg}$-calcite and dolomite caused by the difference of $\mathrm{Mg}$ content

340 could be up to $4 \%$, and a small change of $\mathrm{Mg} /(\mathrm{Mg}+\mathrm{Ca})$ in dolomite from 0.5 to 0.6

341 could account for $1 \%$ variation in $10^{3} \ln \alpha$ at $300 \mathrm{~K}$ (Fig. 7). Furthermore, the

342 concentration effect may play an important role in controlling $\mathrm{Mg}$ isotope

343 fractionation during carbonates precipitation. Li et al. (2012) measured the $\mathrm{Mg}$

344 isotope fractionation between aqueous solution and $\mathrm{Mg}$-bearing calcite with

$345 \mathrm{Mg} /(\mathrm{Mg}+\mathrm{Ca})$ ranging from 0.008 to 0.149 . According to our calculated results, $10^{3} \ln \alpha$

346 of ${ }^{26} \mathrm{Mg} /{ }^{24} \mathrm{Mg}$ between $\mathrm{Mg}_{1 / 12} \mathrm{Ca}_{11 / 12} \mathrm{CO}_{3}$ and $\mathrm{Mg}_{1 / 6} \mathrm{Ca}_{5 / 6} \mathrm{CO}_{3}$ is up to $-2.1 \%$. Therefore,

347 beyond the possible kinetic effect during the experiments, further research on

348 concentration effect is also needed to understand this discrepancy.

349 Ca isotopic compositions of limestone and dolomite were reported in previous

350 studies (Kasemann et al., 2005; Steuber and Buhl, 2006; Jacobson and Holmden, 2008;

351 Holmden, 2009). A large offset of $\delta^{44 / 40} \mathrm{Ca}$ between dolomite (-1.66 \%o) and limestone 
353 ranging from 0 to 0.474 (Holmden, 2009). Based on our calculated results in Fig. $7 b$,

354 the observed $\delta^{44 / 40} \mathrm{Ca}$ difference $(0.6 \%$ ) between limestone and dolomite may be 355 related to the concentration effect on inter-mineral isotopic fractionation between $356 \mathrm{Mg}_{1 / 12} \mathrm{Ca}_{11 / 12} \mathrm{CO}_{3}$ and dolomite at low temperature (Fig. 7b).

357 Finally, $\mathrm{Ca}$ and $\mathrm{Mg}$ isotopic compositions in marine carbonates have been used to 358 constrain geochemical processes related to paleo-oceanography. For example, $\delta^{44 / 40} \mathrm{Ca}$ 359 variations of marine carbonates are used to infer the changes of global Ca cycling (De 360 La Rocha, 2000; Heuser et al., 2005), and a simply steady-state model of Mg isotopes 361 was used to constrain the oceanic cycling of Mg (Tipper et al., 2006b; Li et al., 2015). 362 Because of the large concentration effects on equilibrium $\mathrm{Mg}$ and $\mathrm{Ca}$ isotopic 363 fractionation among carbonate minerals, cautions need to be exercised in future 364 studies.

\section{5. Conclusions}

366 Our DFT calculations reveal that $\mathrm{Ca}-\mathrm{O}$ and $\mathrm{Mg}-\mathrm{O}$ bond lengths in carbonates are 367 sensitive to their $\mathrm{Mg}$ and $\mathrm{Ca}$ contents. $\mathrm{Mg}-\mathrm{O}$ bond length decreases rapidly with 368 increasing $\mathrm{Mg} /(\mathrm{Mg}+\mathrm{Ca})$ when $\mathrm{Mg} /(\mathrm{Mg}+\mathrm{Ca})<1 / 2$. However, when $\mathrm{Mg} /(\mathrm{Mg}+\mathrm{Ca})>$ $3691 / 2, \mathrm{Mg}-\mathrm{O}$ bond length increases with increasing $\mathrm{Mg} /(\mathrm{Mg}+\mathrm{Ca})$, because $\mathrm{Mg}$ atoms 370 begin to occupy the $\mathrm{Ca}$ sites of dolomite, which results in much longer $\mathrm{Mg}-\mathrm{O}$ bond 371 length than $\mathrm{Mg}$ atoms in $\mathrm{Mg}$ sites of dolomite. $\mathrm{Ca}-\mathrm{O}$ bond length increases slightly 372 with increasing $\mathrm{Mg} /(\mathrm{Mg}+\mathrm{Ca})$ when $\mathrm{Mg} /(\mathrm{Mg}+\mathrm{Ca})<1 / 2$, then it decreases with 
373 increasing $\mathrm{Mg} /(\mathrm{Mg}+\mathrm{Ca})$ when $\mathrm{Mg} /(\mathrm{Mg}+\mathrm{Ca})>1 / 2$, with dolomite having the longest

$374 \mathrm{Ca}-\mathrm{O}$ bond and the shortest $\mathrm{Mg}-\mathrm{O}$ bond lengths among carbonate minerals. Such 375 concentration effect on $\mathrm{Ca}-\mathrm{O}$ bond length is most prominent when $\mathrm{Ca} /(\mathrm{Mg}+\mathrm{Ca})<1 / 6$.

376 The calculated equilibrium fractionation factors of $\mathrm{Mg}-\mathrm{Ca}$ isotopes among 377 carbonate minerals $\left(\mathrm{Mg}_{\mathrm{x}} \mathrm{Ca}_{1-\mathrm{x}} \mathrm{CO}_{3}\right)$ are linearly correlated with their average bond 378 lengths. $\mathrm{Mg} /(\mathrm{Mg}+\mathrm{Ca})$ significantly affects $\mathrm{Mg}$ and $\mathrm{Ca}$ isotope fractionations among 379 carbonates. Dolomite $(\mathrm{Mg} / \mathrm{Ca}=1)$ is enriched in heavy $\mathrm{Mg}$ isotopes but depleted in 380 heavy $\mathrm{Ca}$ isotopes relative to other carbonate minerals. At $300 \mathrm{~K}$, the equilibrium 381 fractionation of $\mathrm{Mg}$ isotopes between $\mathrm{Mg}$-calcite with various $\mathrm{Mg} /(\mathrm{Mg}+\mathrm{Ca})$ and 382 dolomite can be up to $4 \%$, comparable to the observed range of $\delta^{26 / 24} \mathrm{Mg}$ in marine $383 \mathrm{Mg}$-calcite. A small change of $\mathrm{Mg} /(\mathrm{Mg}+\mathrm{Ca})$ in dolomite from 0.5 to 0.6 could 384 produce $1 \%$ variation in $\delta^{26 / 24} \mathrm{Mg}$ at $300 \mathrm{~K}$. Therefore, the concentration effect in 385 carbonate minerals should be taken into account when applying the isotope 386 fractionation coefficients to understand geochemical processes.

\section{Acknowledgments}

388 This work is financially supported by Natural Science Foundation of China 389 (41325011, 41473011, 41090370), State Key Development Program of Basic 390 Research of China (2014CB845905), 111 Project, and Special Program for Applied 391 Research on Super Computation of the NSFC-Guangdong Joint Fund. Shichun Huang 392 acknowledges support from NSF grant EAR-1524387. The computations were 393 conducted partly in Supercomputing Center of the University of Science and 
394 Technology of China. We are grateful to the constructive comments from four 395 anonymous reviewers and editorial handling by Andrew Jacobsen. 


\section{References}

Ader M., Macouin M., Trindade R. I. F., Hadrien M.-H., Yang Z., Sun Z. and Besse J. (2009) A multilayered water column in the Ediacaran Yangtze platform? Insights from carbonate and organic matter paired $\delta^{13}$ C. Earth Planet. Sci. Lett. 288, 213-227.

Althoff P. L. (1977) Structural refinements of dolomite and a magnesian calcite and implications for dolomite formation in the marine environment. Am. Mineral. 62, 772-783.

Antao S. M. and Hassan I. (2009) The orthorhombic structure of $\mathrm{CaCO}_{3}, \mathrm{SrCO}_{3}$, $\mathrm{PbCO}_{3}$ and $\mathrm{BaCO}_{3}$ : linear structural trends. Can. Mineral. 47, 1245-1255.

Bemis B. E., Spero H. J., Bijma J. and Lea D. W. (1998) Reevaluation of the oxygen isotopic composition of planktonic foraminifera: Experimental results and revised paleotemperature equations. Paleoceanography 13, 150-160.

Bigeleisen J. and Mayer M. G. (1947) Calculation of Equilibrium Constants for Isotopic Exchange Reactions. J. Chem. Phys. 15, 261.

Buhl D., Immenhauser A., Smeulders G., Kabiri L. and Richter D. K. (2007) Time series $\delta^{26} \mathrm{Mg}$ analysis in speleothem calcite: Kinetic versus equilibrium fractionation, comparison with other proxies and implications for palaeoclimate research. Chem. Geol. 244, 715-729.

Chang V. T.-C., Makishima A., Belshaw N. S. and O’Nions R. K. (2003) Purification of $\mathrm{Mg}$ from low-Mg biogenic carbonates for isotope ratio determination using multiple collector ICP-MS. J. Anal. At. Spectrom. 18, 296-301.

Chang V. T. C., Williams R. J. P., Makishima A., Belshawl N. S. and O’Nions R. K. (2004) $\mathrm{Mg}$ and $\mathrm{Ca}$ isotope fractionation during $\mathrm{CaCO}_{3}$ biomineralisation. Biochem. Biophys. Res. Commun. 323, 79-85.

Cheng Z., Zhang Z., Hou T., Santosh M., Zhang D. and Ke S. (2015) Petrogenesis of nephelinites from the Tarim Large Igneous Province, NW China: Implications for mantle source characteristics and plume-lithosphere interaction. Lithos 220-223, $164-178$.

DePaolo D. J. (2004) Calcium Isotopic Variations Produced by Biological, Kinetic, Radiogenic and Nucleosynthetic Processes. Rev. Mineral. Geochemistry 55, 255-288.

Drits V. A., McCarty D. K., Sakharov B. and Milliken K. L. (2005) New insight into structural and compositional variability in some ancient excess-Ca dolomite. Can. Mineral. 43, 1255-1290.

Farkaš J., Buhl D., Blenkinsop J. and Veizer J. (2007) Evolution of the oceanic calcium cycle during the late Mesozoic: Evidence from $\delta^{44 / 40} \mathrm{Ca}$ of marine skeletal carbonates. Earth Planet. Sci. Lett. 253, 96-111.

Feng C., Qin T., Huang S., Wu Z. and Huang F. (2014) First-principles investigations of equilibrium calcium isotope fractionation between clinopyroxene and Ca-doped orthopyroxene. Geochim. Cosmochim. Acta 143, 132-142.

Galy A., Bar-Matthews M., Halicz L. and O’Nions R. K. (2002) Mg isotopic 
composition of carbonate: insight from speleothem formation. Earth Planet. Sci. Lett. 201, 105-115.

Giannozzi P., Baroni S., Bonini N., Calandra M., Car R., Cavazzoni C., Ceresoli D., Chiarotti G. L., Cococcioni M., Dabo I., Dal Corso A., de Gironcoli S., Fabris S., Fratesi G., Gebauer R., Gerstmann U., Gougoussis C., Kokalj A., Lazzeri M., Martin-Samos L., Marzari N., Mauri F., Mazzarello R., Paolini S., Pasquarello A., Paulatto L., Sbraccia C., Scandolo S., Sclauzero G., Seitsonen A. P., Smogunov A., Umari P. and Wentzcovitch R. M. (2009) QUANTUM ESPRESSO: a modular and open-source software project for quantum simulations of materials. J. Phys. Condens. Matter 21, 395502.

Gillet P. (1993) Stability of magnesite $\left(\mathrm{MgCO}_{3}\right)$ at mantle pressure and temperature conditions; a Raman spectroscopic study. Am. Mineral. 78, 1328-1331.

Graf D. L. (1961) Crystallographic tables for the rhombohedral carbonates. Am. Mineral. 46, 1283-1316.

Griffith E. M., Schauble E. A., Bullen T. D. and Paytan A. (2008) Characterization of calcium isotopes in natural and synthetic barite. Geochim. Cosmochim. Acta 72, $5641-5658$.

Grzechnik A., Simon P., Gillet P. and McMillan P. (1999) An infrared study of $\mathrm{MgCO}_{3}$ at high pressure. Phys. B Condens. Matter 262, 67-73.

Gunasekaran S., Anbalagan G. and Pandi S. (2006) Raman and infrared spectra of carbonates of calcite structure. J. Raman Spectrosc. 37, 892-899.

Hellwege K. H., Lesch W., Plihal M. and Schaack G. (1970) Zwei-Phononen-Absorptionsspektren und Dispersion der Schwingungszweige in Kristallen der Kalkspatstruktur. Zeitschrift für Phys. A Hadron. Nucl. 232, 61-86.

Heuser A., Eisenhauer A., Böhm F., Wallmann K., Gussone N., Pearson P. N., Nägler T. F. and Dullo W.-C. (2005) Calcium isotope $\left(\delta^{44 / 40} \mathrm{Ca}\right)$ variations of Neogene planktonic foraminifera. Paleoceanography 20, PA2013.

Higgins J. A. and Schrag D. P. (2010) Constraining magnesium cycling in marine sediments using magnesium isotopes. Geochim. Cosmochim. Acta 74, 5039-5053.

Hill P. S. and Schauble E. A. (2008) Modeling the effects of bond environment on equilibrium iron isotope fractionation in ferric aquo-chloro complexes. Geochim. Cosmochim. Acta 72, 1939-1958.

Hippler D., Buhl D., Witbaard R., Richter D. K. and Immenhauser A. (2009) Towards a better understanding of magnesium-isotope ratios from marine skeletal carbonates. Geochim. Cosmochim. Acta 73, 6134-6146.

Hoffman P. F., Kaufman A. J., Halverson G. P. and Schrag D. P. (1998) A Neoproterozoic Snowball Earth. Science. 281, 1342-1346.

Holmden C. (2009) Ca isotope study of Ordovician dolomite, limestone, and anhydrite in the Williston Basin: Implications for subsurface dolomitization and local $\mathrm{Ca}$ cycling. Chem. Geol. 268, 180-188.

Huang F., Chen L., Wu Z. and Wang W. (2013) First-principles calculations of equilibrium $\mathrm{Mg}$ isotope fractionations between garnet, clinopyroxene, 
orthopyroxene, and olivine: Implications for $\mathrm{Mg}$ isotope thermometry. Earth Planet. Sci. Lett. 367, 61-70.

Huang F., Wu Z., Huang S. and Wu F. (2014) First-principles calculations of equilibrium silicon isotope fractionation among mantle minerals. Geochim. Cosmochim. Acta 140, 509-520.

Huang J., Li S.-G., Xiao Y., Ke S., Li W.-Y. and Tian Y. (2015) Origin of low $\delta^{26} \mathrm{Mg}$ Cenozoic basalts from South China Block and their geodynamic implications. Geochim. Cosmochim. Acta 164, 298-317.

Huang S., Farkaš J. and Jacobsen S. B. (2011) Stable calcium isotopic compositions of Hawaiian shield lavas: Evidence for recycling of ancient marine carbonates into the mantle. Geochim. Cosmochim. Acta 75, 4987-4997.

Huang Y. and Fairchild I. J. (2001) Partitioning of $\mathrm{Sr}^{2+}$ and $\mathrm{Mg}^{2+}$ into calcite under karst-analogue experimental conditions. Geochim. Cosmochim. Acta 65, 47-62.

Immenhauser A., Buhl D., Richter D., Niedermayr A., Riechelmann D., Dietzel M. and Schulte U. (2010) Magnesium-isotope fractionation during low-Mg calcite precipitation in a limestone cave - Field study and experiments. Geochim. Cosmochim. Acta 74, 4346-4364.

Jacobson A. D. and Holmden C. (2008) $\delta^{44}$ Ca evolution in a carbonate aquifer and its bearing on the equilibrium isotope fractionation factor for calcite. Earth Planet. Sci. Lett. 270, 349-353.

Jacobson A. D., Zhang Z., Lundstrom C. and Huang F. (2010) Behavior of Mg isotopes during dedolomitization in the Madison Aquifer, South Dakota. Earth Planet. Sci. Lett. 297, 446-452.

Johnston D. T., Poulton S. W., Goldberg T., Sergeev V. N., Podkovyrov V., Vorob'eva N. G., Bekker A. and Knoll A. H. (2012) Late Ediacaran redox stability and metazoan evolution. Earth Planet. Sci. Lett. 335-336, 25-35.

Kasemann S. A., Hawkesworth C. J., Prave A. R., Fallick A. E. and Pearson P. N. (2005) Boron and calcium isotope composition in Neoproterozoic carbonate rocks from Namibia: evidence for extreme environmental change. Earth Planet. Sci. Lett. 231, 73-86.

Kaufman A. and Knoll A. (1995) Neoproterozoic variations in the C-isotopic composition of seawater: stratigraphic and biogeochemical implications. Precambrian Res. 73, 27-49.

Kim S.-T. and O’Neil J. R. (1997) Equilibrium and nonequilibrium oxygen isotope effects in synthetic carbonates. Geochim. Cosmochim. Acta 61, 3461-3475.

Kowalski P. M. and Jahn S. (2011) Prediction of equilibrium Li isotope fractionation between minerals and aqueous solutions at high $\mathrm{P}$ and $\mathrm{T}$ : An efficient ab initio approach. Geochim. Cosmochim. Acta 75, 6112-6123.

Kowalski P. M., Wunder B. and Jahn S. (2013) Ab initio prediction of equilibrium boron isotope fractionation between minerals and aqueous fluids at high $\mathrm{P}$ and $\mathrm{T}$. Geochim. Cosmochim. Acta 101, 285-301.

De La Rocha C. L. (2000) Isotopic Evidence for Variations in the Marine Calcium 
Cycle Over the Cenozoic. Science 289, 1176-1178.

Land L. S. (1998) Failure to Precipitate Dolomite at $25^{\circ} \mathrm{C}$ from Dilute Solution Despite 1000-Fold Oversaturation after 32 Years. Aquat. Geochemistry 4, 361-368.

Lea D. W. (2014) Elemental and Isotopic Proxies of Past Ocean Temperatures. In Treatise on Geochemistry Elsevier. pp. 373-397.

Lejaeghere K., Bihlmayer G., Bjorkman T., Blaha P., Blugel S., Blum V., Caliste D., Castelli I. E., Clark S. J., Dal Corso A., de Gironcoli S., Deutsch T., Dewhurst J. K., Di Marco I., Draxl C., Du ak M., Eriksson O., Flores-Livas J. A., Garrity K. F., Genovese L., Giannozzi P., Giantomassi M., Goedecker S., Gonze X., Granas O., Gross E. K. U., Gulans A., Gygi F., Hamann D. R., Hasnip P. J., Holzwarth N. A. W., Iu an D., Jochym D. B., Jollet F., Jones D., Kresse G., Koepernik K., Kucukbenli E., Kvashnin Y. O., Locht I. L. M., Lubeck S., Marsman M., Marzari N., Nitzsche U., Nordstrom L., Ozaki T., Paulatto L., Pickard C. J., Poelmans W., Probert M. I. J., Refson K., Richter M., Rignanese G.-M., Saha S., Scheffler M., Schlipf M., Schwarz K., Sharma S., Tavazza F., Thunstrom P., Tkatchenko A., Torrent M., Vanderbilt D., van Setten M. J., Van Speybroeck V., Wills J. M., Yates J. R., Zhang G.-X. and Cottenier S. (2016) Reproducibility in density functional theory calculations of solids. Science 351, aad3000-aad3000.

Li W.-Y., Teng F.-Z., Xiao Y. and Huang J. (2011) High-temperature inter-mineral magnesium isotope fractionation in eclogite from the Dabie orogen, China. Earth Planet. Sci. Lett. 304, 224-230.

Li W., Beard B. L., Li C., Xu H. and Johnson C. M. (2015) Experimental calibration of $\mathrm{Mg}$ isotope fractionation between dolomite and aqueous solution and its geological implications. Geochim. Cosmochim. Acta 157, 164-181.

Li W., Chakraborty S., Beard B. L., Romanek C. S. and Johnson C. M. (2012) Magnesium isotope fractionation during precipitation of inorganic calcite under laboratory conditions. Earth Planet. Sci. Lett. 333-334, 304-316.

Li X. and Liu Y. (2011) Equilibrium Se isotope fractionation parameters: A first-principles study. Earth Planet. Sci. Lett. 304, 113-120.

Liu D., Zhao Z., Zhu D.-C., Niu Y., Widom E., Teng F.-Z., DePaolo D. J., Ke S., Xu J.-F., Wang Q. and Mo X. (2015) Identifying mantle carbonatite metasomatism through Os-Sr-Mg isotopes in Tibetan ultrapotassic rocks. Earth Planet. Sci. Lett. 430, 458-469.

Markgraf S. and Reeder R. (1985) High-temperature structure refinements of calcite and magnesite. Am. Miner. 70, 590-600.

Mavromatis V., Gautier Q., Bosc O. and Schott J. (2013) Kinetics of Mg partition and $\mathrm{Mg}$ stable isotope fractionation during its incorporation in calcite. Geochim. Cosmochim. Acta 114, 188-203.

McDermott F. (2004) Palaeo-climate reconstruction from stable isotope variations in speleothems: a review. Quat. Sci. Rev. 23, 901-918.

Méheut M., Lazzeri M., Balan E. and Mauri F. (2009) Structural control over equilibrium silicon and oxygen isotopic fractionation: A first-principles 

density-functional theory study. Chem. Geol. 258, 28-37.

Meldrum F. C. and Hyde S. T. (2001) Morphological influence of magnesium and organic additives on the precipitation of calcite. J. Cryst. Growth 231, 544-558.

Meyer K. M., Yu M., Lehrmann D., van de Schootbrugge B. and Payne J. L. (2013) Constraints on Early Triassic carbon cycle dynamics from paired organic and inorganic carbon isotope records. Earth Planet. Sci. Lett. 361, 429-435.

Momma K. and Izumi F. (2008) VESTA : a three-dimensional visualization system for electronic and structural analysis. J. Appl. Crystallogr. 41, 653-658.

Mucci A. (1986) Growth kinetics and composition of magnesian calcite overgrowths precipitated from seawater: Quantitative influence of orthophosphate ions. Geochim. Cosmochim. Acta 50, 2255-2265.

Mucci A. and Morse J. W. (1983) The incorporation of $\mathrm{Mg}^{2+}$ and $\mathrm{Sr}^{2+}$ into calcite overgrowths: influences of growth rate and solution composition. Geochim. Cosmochim. Acta 47, 217-233.

Paquette J. and Reeder R. J. (1990) Single-crystal X-ray structure refinements of two biogenic magnesian calcite crystals. Am. Mineral. 75, 1151-1158.

Pearce C. R., Saldi G. D., Schott J. and Oelkers E. H. (2012) Isotopic fractionation during congruent dissolution, precipitation and at equilibrium: Evidence from $\mathrm{Mg}$ isotopes. Geochim. Cosmochim. Acta 92, 170-183.

Perdew J. P. and Zunger A. (1981) Self-interaction correction to density-functional approximations for many-electron systems. Phys. Rev. B 23, 5048-5079.

Pinilla C., Blanchard M., Balan E., Natarajan S. K., Vuilleumier R. and Mauri F. (2015) Equilibrium magnesium isotope fractionation between aqueous $\mathrm{Mg} 2+$ and carbonate minerals: Insights from path integral molecular dynamics. Geochim. Cosmochim. Acta 163, 126-139.

Reeder R. J. and Markgraf S. A. (1986) High-temperature crystal chemistry of dolomite. Am. Mineral. 7, 795-804.

Reeder R. J. and Wenk H. R. (1983) Structure refinements of some thermally disordered dolomites. Am. Mineral. 68, 769-776.

Richet P., Bottinga Y. and Javoy M. (1977) A Review of Hydrogen, Carbon, Nitrogen, Oxygen, Sulphur, and Chlorine Stable Isotope Fractionation Among Gaseous Molecules. Annu. Rev. Earth Planet. Sci. 5, 65-110.

Ross N. L. and Reeder R. J. (1992) High-pressure structural study of dolomite and ankerite. Am. Mineral. 77, 412-421.

Rustad J. R., Casey W. H., Yin Q.-Z., Bylaska E. J., Felmy A. R., Bogatko S. A., Jackson V. E. and Dixon D. A. (2010) Isotopic fractionation of $\mathrm{Mg}^{2+}(\mathrm{aq}), \mathrm{Ca}^{2+}(\mathrm{aq})$, and $\mathrm{Fe}^{2+}(\mathrm{aq})$ with carbonate minerals. Geochim. Cosmochim. Acta 74, 6301-6323.

Saenger C. and Wang Z. (2014) Magnesium isotope fractionation in biogenic and abiogenic carbonates: Implications for paleoenvironmental proxies. Quat. Sci. Rev. 90, $1-21$.

Sahoo S. K., Planavsky N. J., Kendall B., Wang X., Shi X., Scott C., Anbar A. D., Lyons T. W. and Jiang G. (2012) Ocean oxygenation in the wake of the Marinoan 

glaciation. Nature 489, 546-9.

Saulnier S., Rollion-Bard C., Vigier N. and Chaussidon M. (2012) Mg isotope fractionation during calcite precipitation: An experimental study. Geochim. Cosmochim. Acta 91, 75-91.

Schauble E. A. (2011) First-principles estimates of equilibrium magnesium isotope fractionation in silicate, oxide, carbonate and hexaaquamagnesium(2+) crystals. Geochim. Cosmochim. Acta 75, 844-869.

Schauble E., Rossman G. R. and Taylor H. P. (2004) Theoretical estimates of equilibrium chromium-isotope fractionations. Chem. Geol. 205, 99-114.

Shields-Zhou G. and Och L. (2011) The case for a Neoproterozoic Oxygenation Event: Geochemical evidence and biological consequences. GSA Today 21, 4-11.

Steuber T. and Buhl D. (2006) Calcium-isotope fractionation in selected modern and ancient marine carbonates. Geochim. Cosmochim. Acta 70, 5507-5521..

Tesoriero A. J. and Pankow J. F. (1996) Solid solution partitioning of $\mathrm{Sr}^{2+}, \mathrm{Ba}^{2+}$, and $\mathrm{Cd}^{2+}$ to calcite. Geochim. Cosmochim. Acta 60, 1053-1063.

Tipper E. T., Galy A. and Bickle M. J. (2006) Riverine evidence for a fractionated reservoir of $\mathrm{Ca}$ and $\mathrm{Mg}$ on the continents: Implications for the oceanic Ca cycle. Earth Planet. Sci. Lett. 247, 267-279.

Tipper E. T., Galy A., Gaillardet J., Bickle M. J., Elderfield H. and Carder E. A. (2006) The magnesium isotope budget of the modern ocean: Constraints from riverine magnesium isotope ratios. Earth Planet. Sci. Lett. 250, 241-253.

Troullier N. and Martins J. L. (1991) Efficient pseudopotentials for plane-wave calculations. II. Operators for fast iterative diagonalization. Phys. Rev. B 43, 8861-8869.

Urey H. C. (1947) The thermodynamic properties of isotopic substances ed. S.-I. Karato. J. Chem. Soc., 562.

Urmos J., Sharma S. K. and Mackenzie F. T. (1991) Characterization of some biogenic carbonates with Raman spectroscopy. Am. Mineral. 76, 641-646.

Vanderbilt D. (1990) Soft self-consistent pseudopotentials in a generalized eigenvalue formalism. Phys. Rev. B 41, 7892-7895.

de Villiers S., Dickson J. A. D. and Ellam R. M. (2005) The composition of the continental river weathering flux deduced from seawater $\mathrm{Mg}$ isotopes. Chem. Geol. 216, 133-142.

Warren J. (2000) Dolomite: Occurence, evolution and economically important associations. Earth Sci. Rev. 52, 1-81.

Weir C. E. and Lippincott E. R. (1961) Infrared studies of aragonite, calcite, and vaterite type structures in the borates, carbonates, and nitrates. J. Res. Natl. Bur. Stand. Sect. A Phys. Chem. 65A, 173.

Wentzcovitch R. M. (1991) Invariant molecular-dynamics approach to structural phase transitions. Phys. Rev. B 44, 2358-2361.

Wentzcovitch R. M., Yu Y. G. and Wu Z. (2010) Thermodynamic Properties and Phase Relations in Mantle Minerals Investigated by First Principles Quasiharmonic 

Theory. Rev. Mineral. Geochemistry 71, 59-98.

Werne J. P. and Hollander D. J. (2004) Balancing supply and demand: controls on carbon isotope fractionation in the Cariaco Basin (Venezuela) Younger Dryas to present. Mar. Chem. 92, 275-293.

Wu Z., Huang F. and Huang S. (2015) Isotope fractionation induced by phase transformation: First-principles investigation for $\mathrm{Mg}_{2} \mathrm{SiO}_{4}$. Earth Planet. Sci. Lett. 409, 339-347.

Yang W., Teng F.-Z., Zhang H.-F. and Li S.-G. (2012) Magnesium isotopic systematics of continental basalts from the North China craton: Implications for tracing subducted carbonate in the mantle. Chem. Geol. 328, 185-194.

Young E. D., Tonui E., Manning C. E., Schauble E. and Macris C. A. (2009) Spinel-olivine magnesium isotope thermometry in the mantle and implications for the $\mathrm{Mg}$ isotopic composition of Earth. Earth Planet. Sci. Lett. 288, 524-533.

Zenger D. H., Dunham J. B. and Ethington R. L. (1980) Concepts and Models of Dolomitization. eds. D. H. Zenger, J. B. Dunham, and R. L. Ethington, SEPM (Society for Sedimentary Geology).

Zhang H. and Li S. (2012) Deep carbon recycling and isotope tracing: Review and prospect. Sci. China Earth Sci. 55, 1929-1941.

666

667 
668 Tables

669 Table 1. Average $\mathrm{Mg}-\mathrm{O}$ and $\mathrm{Ca}-\mathrm{O}$ bond lengths in carbonates at static condition.

670

\begin{tabular}{cccccc}
\hline \multirow{2}{*}{ Minerals } & $\mathrm{Mg} /(\mathrm{Mg}+\mathrm{Ca})$ & \multicolumn{3}{c}{ Average bond length $(\AA)$} \\
\cline { 3 - 6 } & 0 & $\mathrm{Mg}-\mathrm{O}$ & Exp. & $\mathrm{Ca}-\mathrm{O}$ & Exp. \\
\hline & $1 / 12$ & 2.093 & & 2.341 & $2.360^{\dagger}$ \\
& $1 / 6$ & 2.074 & & 2.341 & \\
& $2 / 12$ & 2.075 & & 2.343 & \\
& $2 / 6$ & 2.061 & & 2.350 & \\
Calcite-type & $3 / 6$ & 2.057 & $2.082^{\ddagger}$ & 2.361 & $2.381^{\ddagger}$ \\
& $4 / 6$ & 2.073 & & 2.351 & \\
& $5 / 6$ & 2.078 & & 2.336 & \\
& $11 / 12$ & 2.082 & & 2.292 & \\
& $23 / 24$ & 2.080 & & 2.274 & \\
& $35 / 36$ & 2.079 & & 2.273 & \\
Aragonite & $6 / 6$ & 2.076 & $2.102^{\dagger}$ & & \\
& $6 / 6$ & & & 2.491 & $2.529^{*}$
\end{tabular}

671 Experimental results: $\uparrow$, Markgraf and Reeder (1985); $\downarrow$, Reeder and Markgraf (1986);

$672 *$, Antao and Hassan, (2009). 
673 Table 2. Polynomial fitting parameters of the calculated reduced partition function 674 ratios $\left(10^{3} \ln \beta\right)$ of ${ }^{26} \mathrm{Mg} /{ }^{24} \mathrm{Mg}$ and ${ }^{44} \mathrm{Ca} /{ }^{40} \mathrm{Ca}$ for calcite-type carbonate minerals with 675 variable $\mathrm{Mg} /(\mathrm{Mg}+\mathrm{Ca})$ and aragonite.

676

\begin{tabular}{|c|c|c|c|c|c|}
\hline Element & Minerals & $\mathrm{Mg} /(\mathrm{Mg}+\mathrm{Ca})$ & $\mathrm{a}$ & $\mathrm{b}$ & $\mathrm{c}$ \\
\hline \multirow{11}{*}{${ }^{26} \mathrm{Mg} /{ }^{24} \mathrm{Mg}$} & \multirow{11}{*}{ Calcite-type } & $1 / 12$ & 2.13577 & -0.01317 & $1.91 \mathrm{E}-04$ \\
\hline & & $1 / 6$ & 2.34829 & -0.01509 & $2.07 \mathrm{E}-04$ \\
\hline & & $2 / 12$ & 2.32144 & -0.01485 & $1.89 \mathrm{E}-04$ \\
\hline & & $2 / 6$ & 2.50481 & -0.01689 & $2.29 \mathrm{E}-04$ \\
\hline & & $3 / 6$ & 2.57088 & -0.01774 & $2.40 \mathrm{E}-04$ \\
\hline & & $4 / 6$ & 2.42347 & -0.01649 & $2.34 \mathrm{E}-04$ \\
\hline & & $5 / 6$ & 2.39560 & -0.01643 & $2.40 \mathrm{E}-04$ \\
\hline & & $11 / 12$ & 2.36599 & -0.01654 & $2.46 \mathrm{E}-04$ \\
\hline & & $23 / 24$ & 2.39509 & -0.01657 & $2.42 \mathrm{E}-04$ \\
\hline & & $35 / 36$ & 2.39067 & -0.01661 & $2.45 \mathrm{E}-04$ \\
\hline & & $6 / 6$ & 2.42674 & -0.01688 & $2.48 \mathrm{E}-04$ \\
\hline \multirow[t]{12}{*}{${ }^{44} \mathrm{Ca} /{ }^{40} \mathrm{Ca}$} & Aragonite & $0 / 6$ & 1.23384 & -0.00749 & $1.66 \mathrm{E}-04$ \\
\hline & \multirow{11}{*}{ Calcite-type } & $0 / 6$ & 1.49037 & -0.00729 & $1.07 \mathrm{E}-04$ \\
\hline & & $1 / 12$ & 1.49703 & -0.00758 & $1.12 \mathrm{E}-04$ \\
\hline & & $1 / 6$ & 1.48731 & -0.00748 & $1.11 \mathrm{E}-04$ \\
\hline & & $2 / 12$ & 1.47687 & -0.00710 & 0.93E-04 \\
\hline & & $2 / 6$ & 1.44802 & -0.00737 & $1.13 \mathrm{E}-04$ \\
\hline & & $3 / 6$ & 1.39204 & -0.00715 & $1.15 \mathrm{E}-04$ \\
\hline & & $4 / 6$ & 1.43798 & -0.00762 & $1.21 \mathrm{E}-04$ \\
\hline & & $5 / 6$ & 1.52317 & -0.00839 & $1.30 \mathrm{E}-04$ \\
\hline & & $11 / 12$ & 1.83571 & -0.01157 & $1.65 \mathrm{E}-04$ \\
\hline & & $23 / 24$ & 1.97478 & -0.01331 & $1.85 \mathrm{E}-04$ \\
\hline & & $35 / 36$ & 1.99278 & -0.01331 & $1.87 \mathrm{E}-04$ \\
\hline
\end{tabular}

$67710^{3} \ln \beta=a x+b x^{2}+c x^{3}$, where $x=10^{6} / T^{2} . T$ is temperature in Kelvin. All

678 polynomial fittings are performed between $273 \mathrm{~K}$ to $2500 \mathrm{~K}$. 
679 Table 3. Polynomial fitting parameters of $10^{3} \ln \alpha_{\text {minerals-dolomite }}$ of ${ }^{26} \mathrm{Mg} /{ }^{24} \mathrm{Mg}$ 680 and ${ }^{44} \mathrm{Ca} /{ }^{40} \mathrm{Ca}$. Minerals include calcite-type carbonate minerals with variable $681 \mathrm{Mg} /(\mathrm{Mg}+\mathrm{Ca})$ and aragonite.

682

\begin{tabular}{cccccc}
\hline Element & Minerals & $\mathrm{Mg} /(\mathrm{Mg}+\mathrm{Ca})$ & $\mathrm{a}$ & $\mathrm{b}$ & $\mathrm{c}$ \\
\hline${ }^{26} \mathrm{Mg} /{ }^{24} \mathrm{Mg}$ & $1 / 12$ & -0.43511 & $4.6 \mathrm{E}-03$ & $-4.9 \mathrm{E}-05$ \\
& & $1 / 6$ & -0.22259 & $2.7 \mathrm{E}-03$ & $-3.3 \mathrm{E}-05$ \\
& & & & \\
& & & & & \\
& & & & & \\
& Calcite-type & $4 / 6$ & -0.06607 & $8.5 \mathrm{E}-04$ & $-1.1 \mathrm{E}-05$ \\
& & $5 / 6$ & -0.14741 & $1.3 \mathrm{E}-03$ & $-6.0 \mathrm{E}-06$ \\
& & $11 / 12$ & -0.20489 & $1.2 \mathrm{E}-03$ & $6.0 \mathrm{E}-06$ \\
& & $23 / 24$ & -0.17579 & $1.2 \mathrm{E}-03$ & $2.0 \mathrm{E}-06$ \\
& & $35 / 36$ & -0.18021 & $1.1 \mathrm{E}-03$ & $5.0 \mathrm{E}-06$ \\
& & $6 / 6$ & -0.14414 & $8.6 \mathrm{E}-04$ & $8.0 \mathrm{E}-06$ \\
\hline${ }^{44} \mathrm{Ca} /{ }^{40} \mathrm{Ca}$ & Aragonite & $0 / 6$ & -0.15820 & $-3.4 \mathrm{E}-04$ & $5.1 \mathrm{E}-05$ \\
\hline & & $0 / 6$ & 0.09833 & $-1.4 \mathrm{E}-04$ & $-8.0 \mathrm{E}-06$ \\
& & $1 / 12$ & 0.10499 & $-4.3 \mathrm{E}-04$ & $-3.0 \mathrm{E}-06$ \\
& & $1 / 6$ & 0.09527 & $-3.3 \mathrm{E}-04$ & $-4.0 \mathrm{E}-06$ \\
& & $2 / 12$ & 0.08483 & $5.0 \mathrm{E}-05$ & $-2.2 \mathrm{E}-05$ \\
& & $2 / 6$ & 0.05598 & $-2.2 \mathrm{E}-04$ & $-2.0 \mathrm{E}-06$ \\
& & $4 / 6$ & 0.04594 & $-4.7 \mathrm{E}-04$ & $6.0 \mathrm{E}-06$ \\
& & $5 / 6$ & 0.13113 & $-1.2 \mathrm{E}-03$ & $1.5 \mathrm{E}-05$ \\
& & $11 / 12$ & 0.44367 & $-4.4 \mathrm{E}-03$ & $5.0 \mathrm{E}-05$ \\
& & $23 / 24$ & 0.58274 & $-6.2 \mathrm{E}-03$ & $7.0 \mathrm{E}-05$ \\
& & 0.60074 & $-6.2 \mathrm{E}-03$ & $7.2 \mathrm{E}-05$ \\
\hline & & & &
\end{tabular}

683

$68410^{3} \ln \alpha_{\text {minerals-dolomite }}=a x+b x^{2}+c x^{3}$, where $x=10^{6} / T^{2} . T$ is temperature 685 in Kelvin. All polynomial fittings are performed between $273 \mathrm{~K}$ to $2500 \mathrm{~K}$. 


\section{Figure Captions}

687 Figure 1. Carbonate crystal structures with variable $\mathrm{Mg} /(\mathrm{Mg}+\mathrm{Ca})$ with emphasis on $\mathrm{Mg}-\mathrm{O}$ and $\mathrm{Ca}-\mathrm{O}$ polyhedrons. $\mathrm{Mg}$ atoms are brown, $\mathrm{Ca}$ atoms cyan, $\mathrm{C}$ atoms dark brown, and $\mathrm{O}$ atoms red. All of these crystal structures are drawn using the software "VESTA" (Momma and Izumi, 2008).

691 static condition. The black solid line shows that static volumes vary with $\mathrm{Mg} /(\mathrm{Mg}+\mathrm{Ca})$. In order to correct the temperature effect, these volumes at ambient condition were estimated using calculated expansion volume of calcite at $300 \mathrm{~K}$, which increases by $1.8 \%$ compared to the static volume of calcite (Table S3), as shown by the dash line. The relative difference between black dash line and experimental data is less than 1\% (Althoff, 1977; Reeder and Wenk, 1983; Markgraf and Reeder, 1985; Reeder and Markgraf, 1986; Paquette and Reeder, 1990; Ross and Reeder, 1992; Drits et al., 2005).

Figure 3. Calculated frequencies of calcite, dolomite, magnesite and aragonite are compared to measured frequencies (more details in Table S4).

Figure 4. Average (a) $\mathrm{Mg}-\mathrm{O}$ bond and (b) $\mathrm{Ca}-\mathrm{O}$ bond length of carbonate minerals verus $\mathrm{Mg} /(\mathrm{Mg}+\mathrm{Ca})$.

Figure 5. (a) $\mathrm{Mg}$ isotope $\beta$-factors of calcite-type carbonate minerals, and (b) $\mathrm{Ca}$ isotope $\beta$-factors of calcite-type carbonate minerals and aragonite as a function of temperatures.

Figure 6. Temperature dependence of the $10^{3} \ln \alpha_{\text {minerals-dolomite }}$ of (a) $\mathrm{Mg}$ 

isotopes and (b) $\mathrm{Ca}$ isotopes. Calcite-type carbonate minerals are always enriched in lighter $\mathrm{Mg}$ isotopes and heavier $\mathrm{Ca}$ isotopes relative to dolomite. Aragonite is enriched in light $\mathrm{Ca}$ isotopes relative to calcite-type carbonate minerals.

712 Figure 7. $10^{3} \ln \alpha_{\text {minerals-dolomite }}$ of (a) ${ }^{26} \mathrm{Mg} /{ }^{24} \mathrm{Mg}$ and (b) ${ }^{44} \mathrm{Ca} /{ }^{40} \mathrm{Ca}$ vary with 713 $\mathrm{Mg} /(\mathrm{Mg}+\mathrm{Ca})$ in calcite-type carbonate minerals.

714 Figure 8 . The negative correlations between $10^{3} \ln \alpha_{\text {minerals-dolomite }}$ of $\mathrm{Mg}$ and $\mathrm{Ca}$ isotopes and relative average $\mathrm{Mg}-\mathrm{O}$ and $\mathrm{Ca}-\mathrm{O}$ at $300 \mathrm{~K}$ and $1000 \mathrm{~K}$, respectively. Shorter bonds are always enriched in heavy isotopes. 


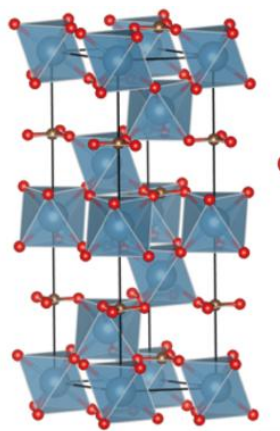

$\mathrm{Mg} /(\mathrm{Mg}+\mathrm{Ca})=0 / 6$

Calcite

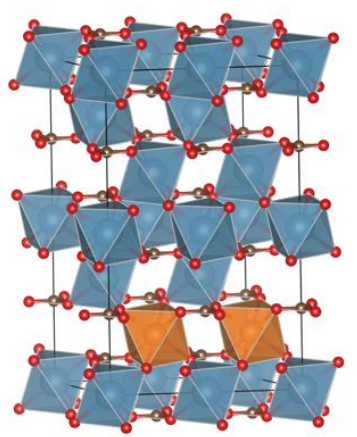

$\mathrm{Mg} /(\mathrm{Mg}+\mathrm{Ca})=2 / 12$

Calcite-type

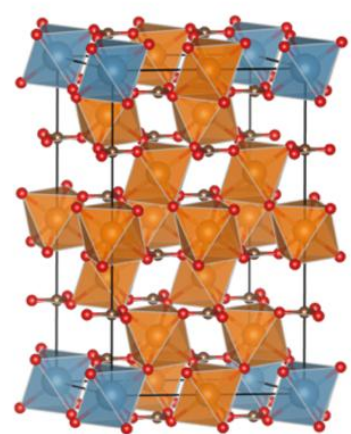

$M g /(M g+C a)=11 / 12$ Calcite-type

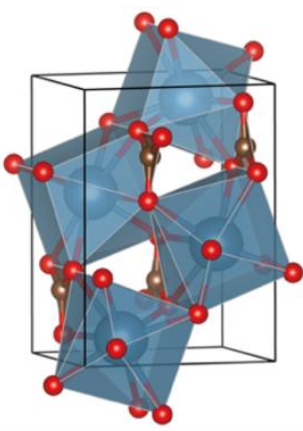

$\mathrm{Mg} /(\mathrm{Mg}+\mathrm{Ca})=0 / 6$ Aragonite

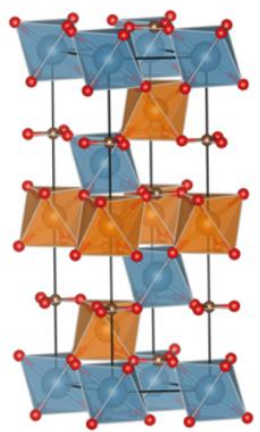

$\mathrm{Mg} /(\mathrm{Mg}+\mathrm{Ca})=3 / 6$ Dolomite

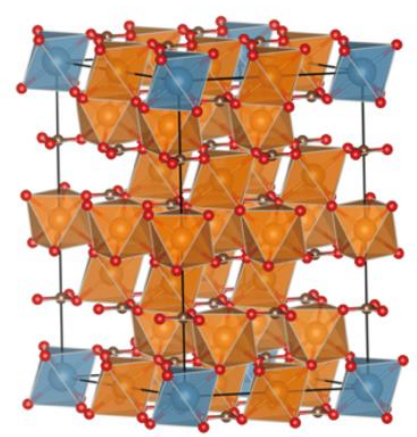

$\mathrm{Mg} /(\mathrm{Mg}+\mathrm{Ca})=23 / 24$

Calcite-type

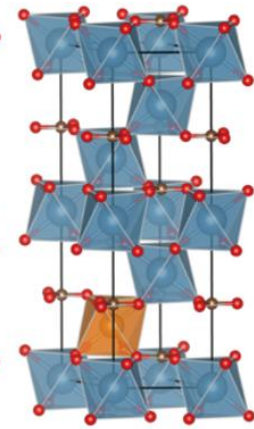

$\mathrm{Mg} /(\mathrm{Mg}+\mathrm{Ca})=1 / 6$ Calcite-type

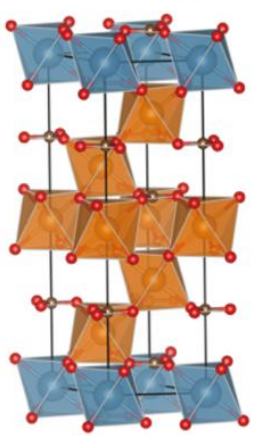

$\mathrm{Mg} /(\mathrm{Mg}+\mathrm{Ca})=5 / 6$ Calcite-type

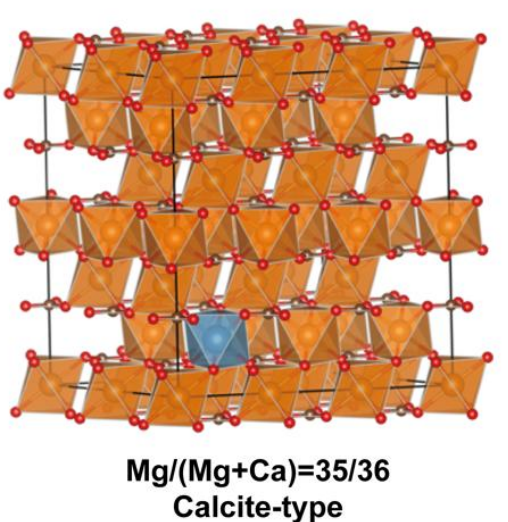

$\mathrm{Mg} /(\mathrm{Mg}+\mathrm{Ca})=35 / 36$ Calcite-type

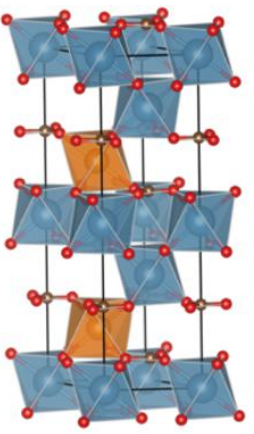

$\mathrm{Mg} /(\mathrm{Mg}+\mathrm{Ca})=2 / 6$ Calcite-type

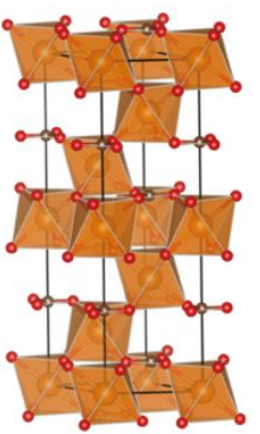

$\mathrm{Mg} /(\mathrm{Mg}+\mathrm{Ca})=6 / 6$ Magnesite
Figure 1. 


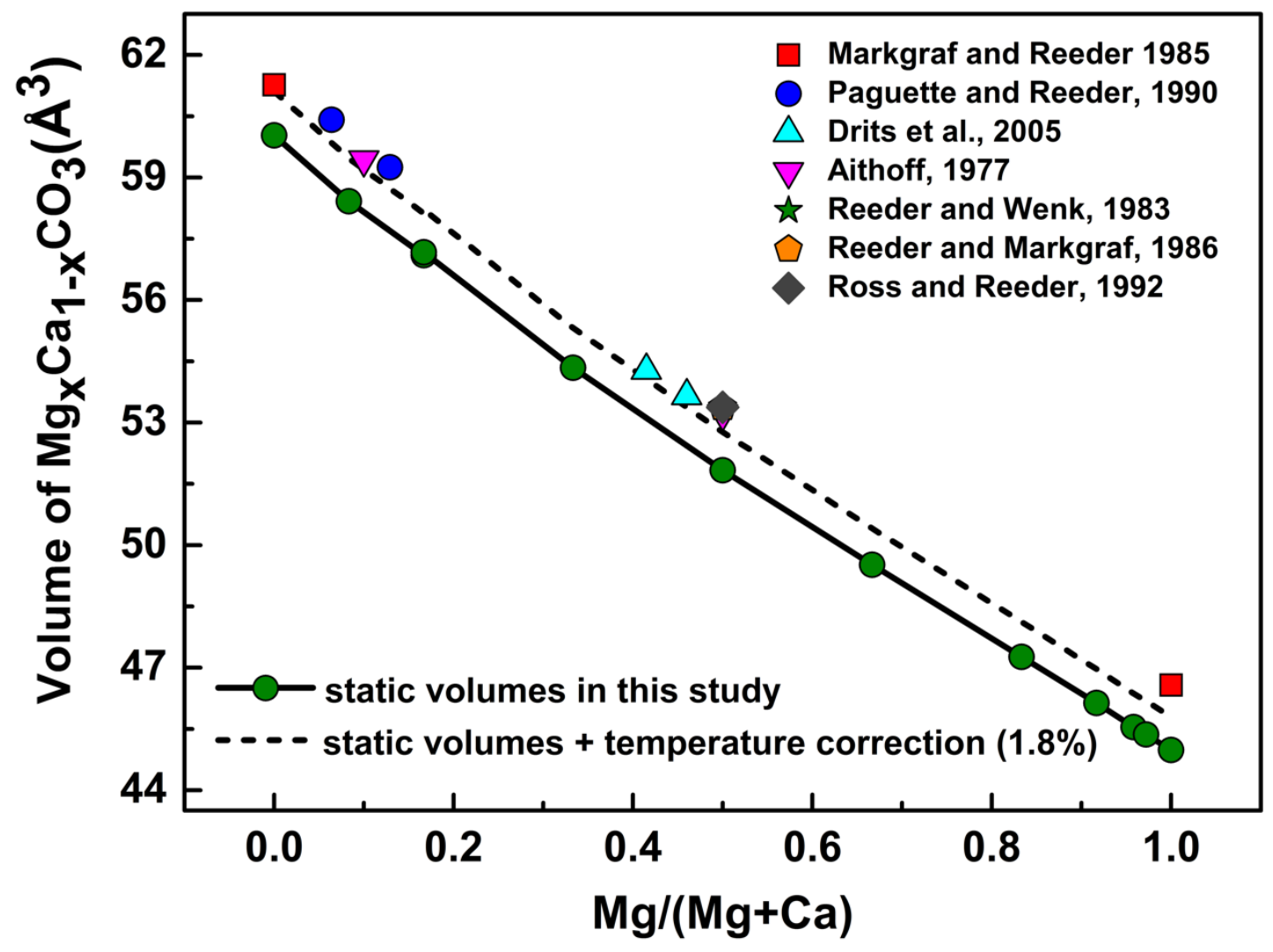

Figure 2. 


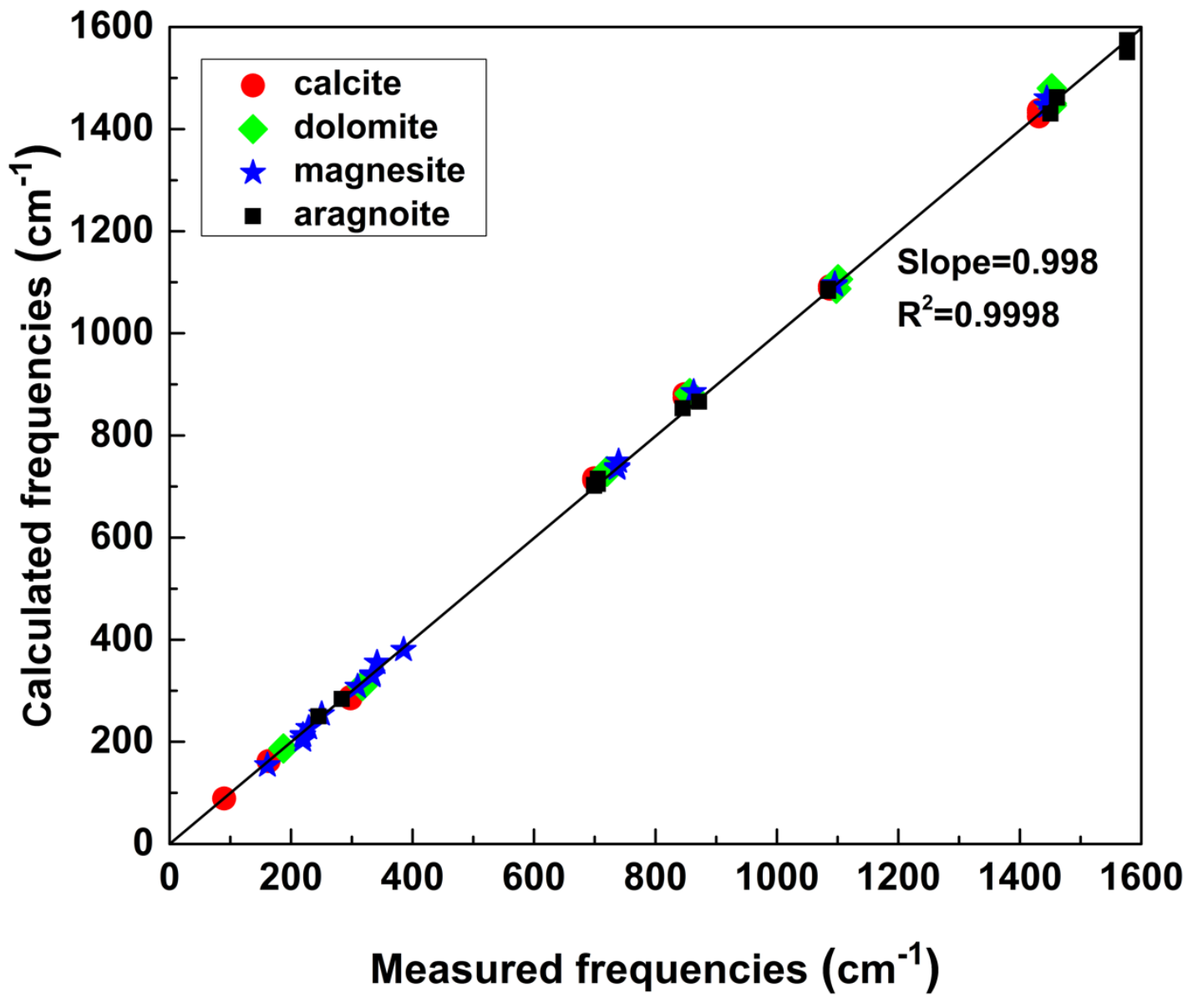

722

Figure 3. 


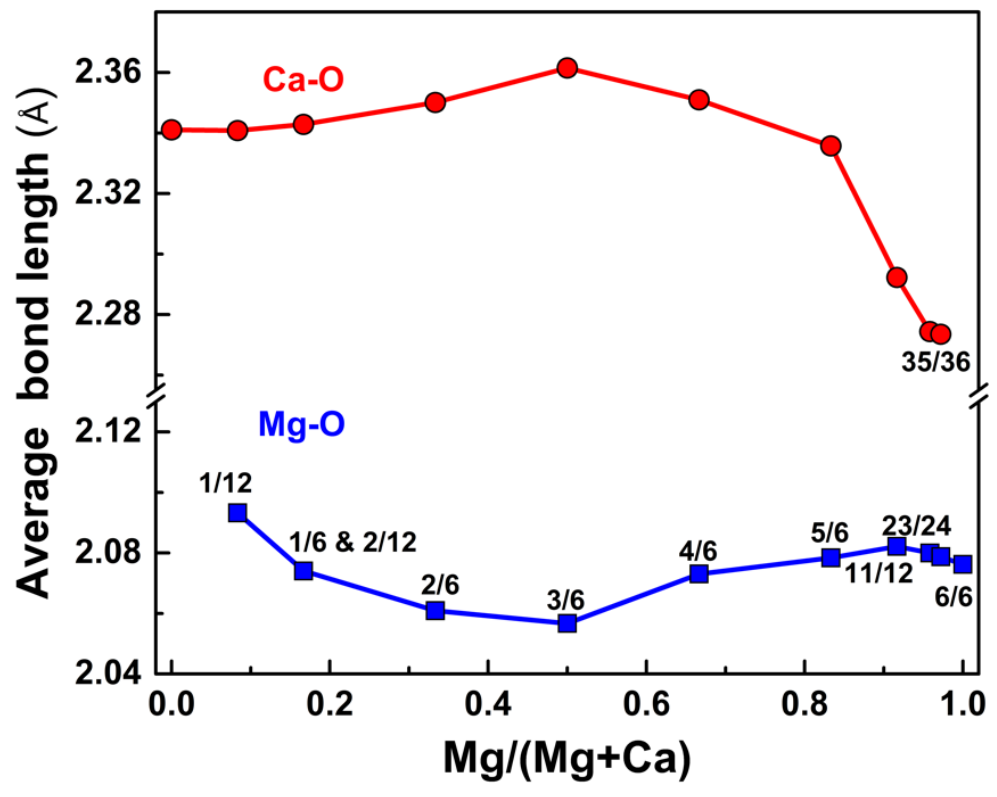

724

Figure 4. 
Temperature(K)
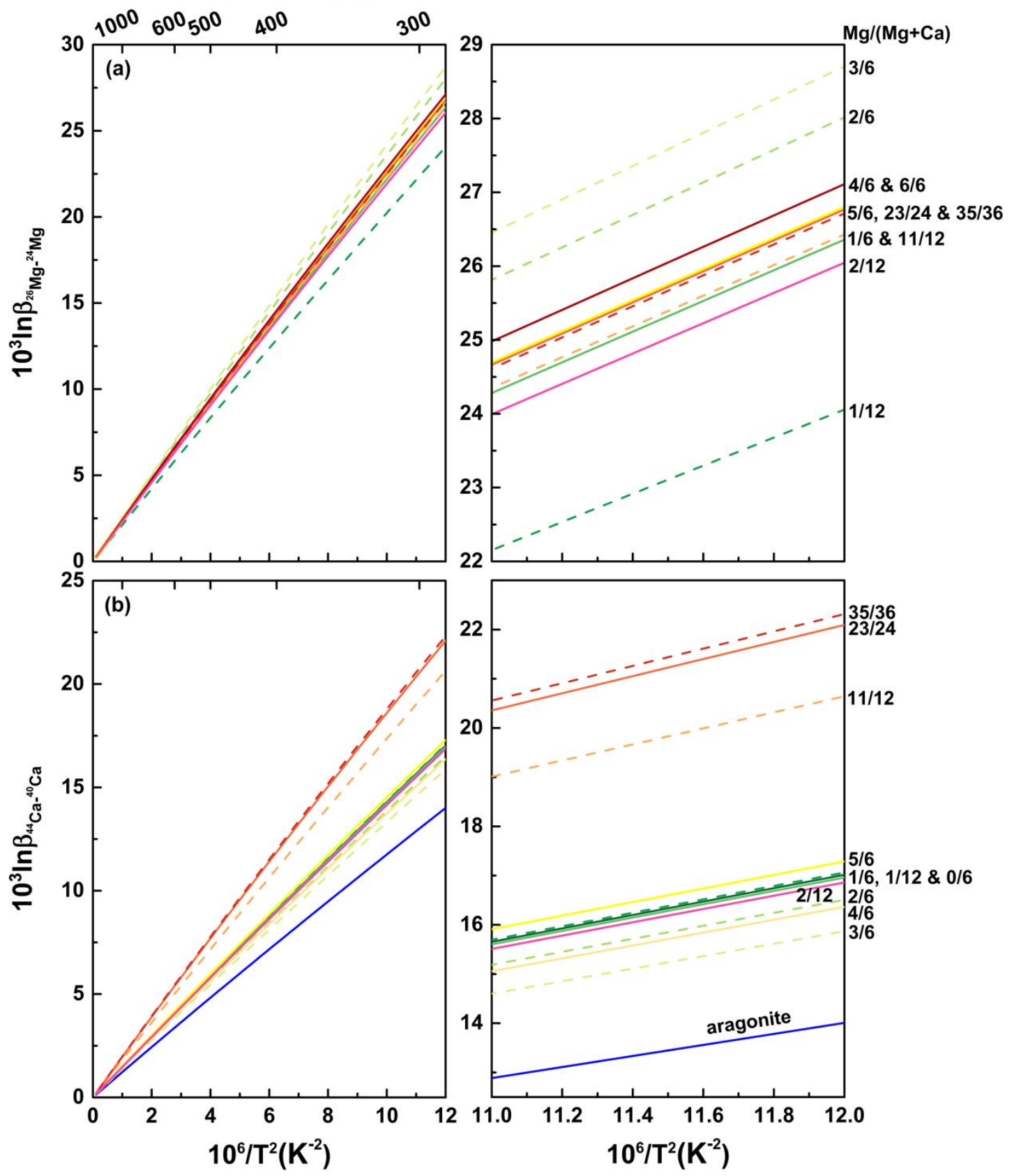

725

726

Figure 5. 

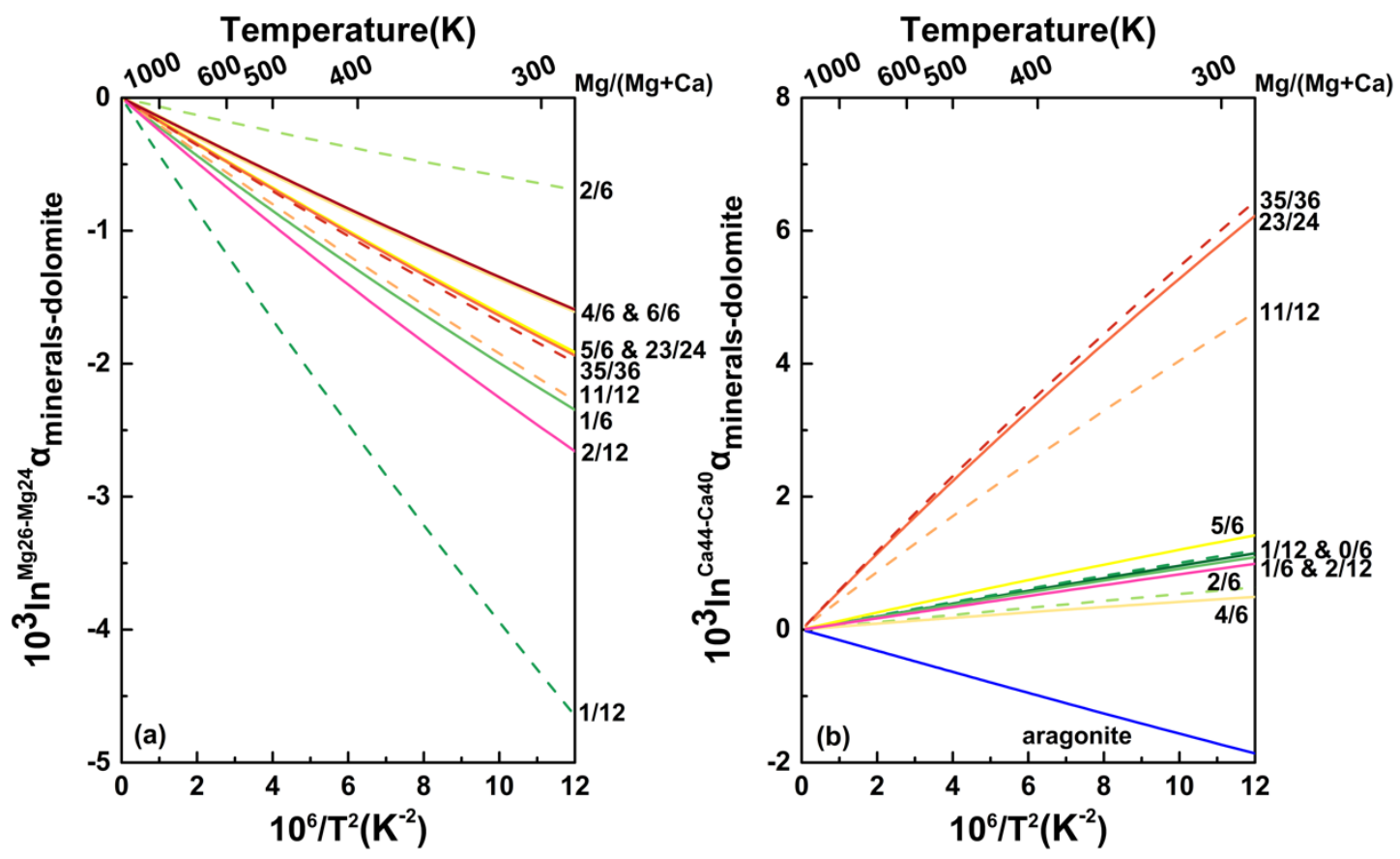

727

Figure 6.

728 


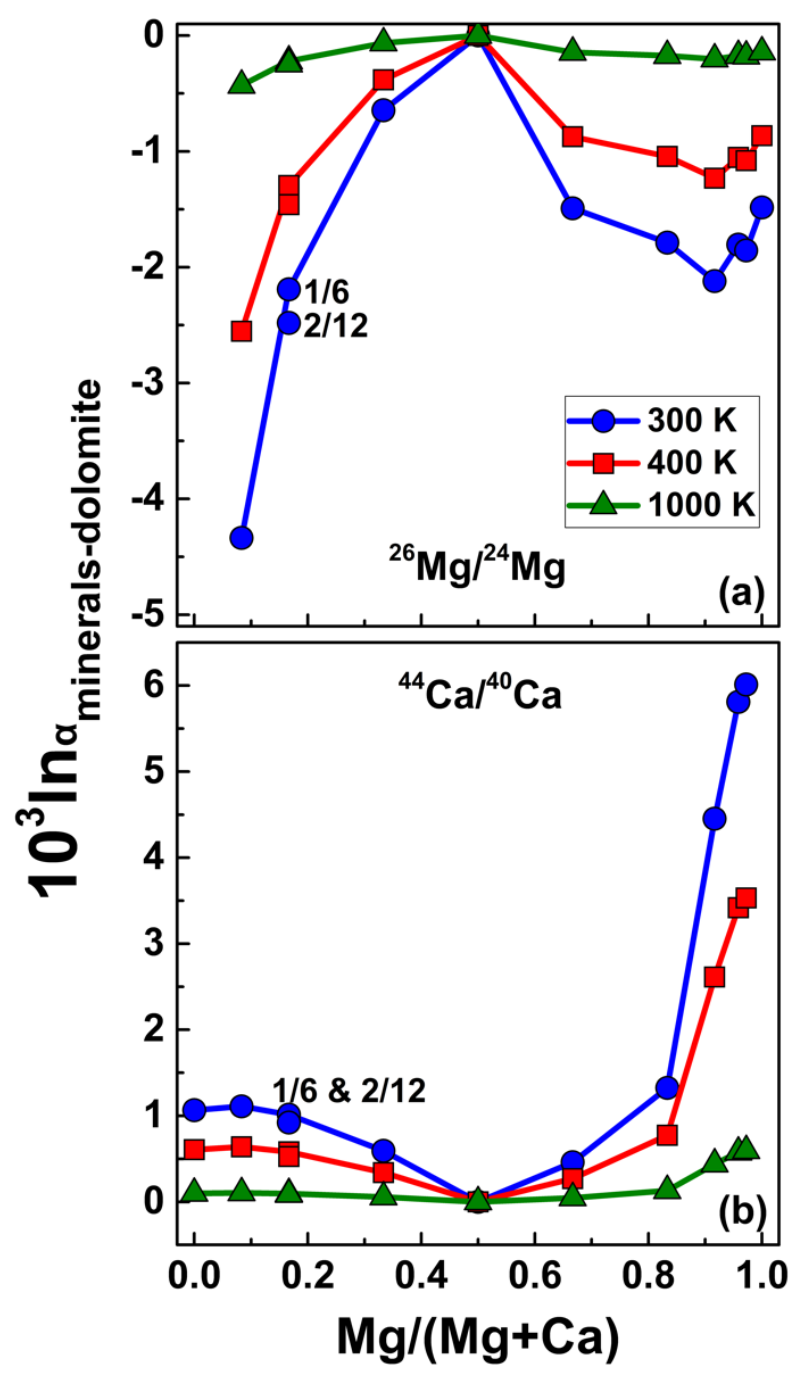

730

Figure 7. 

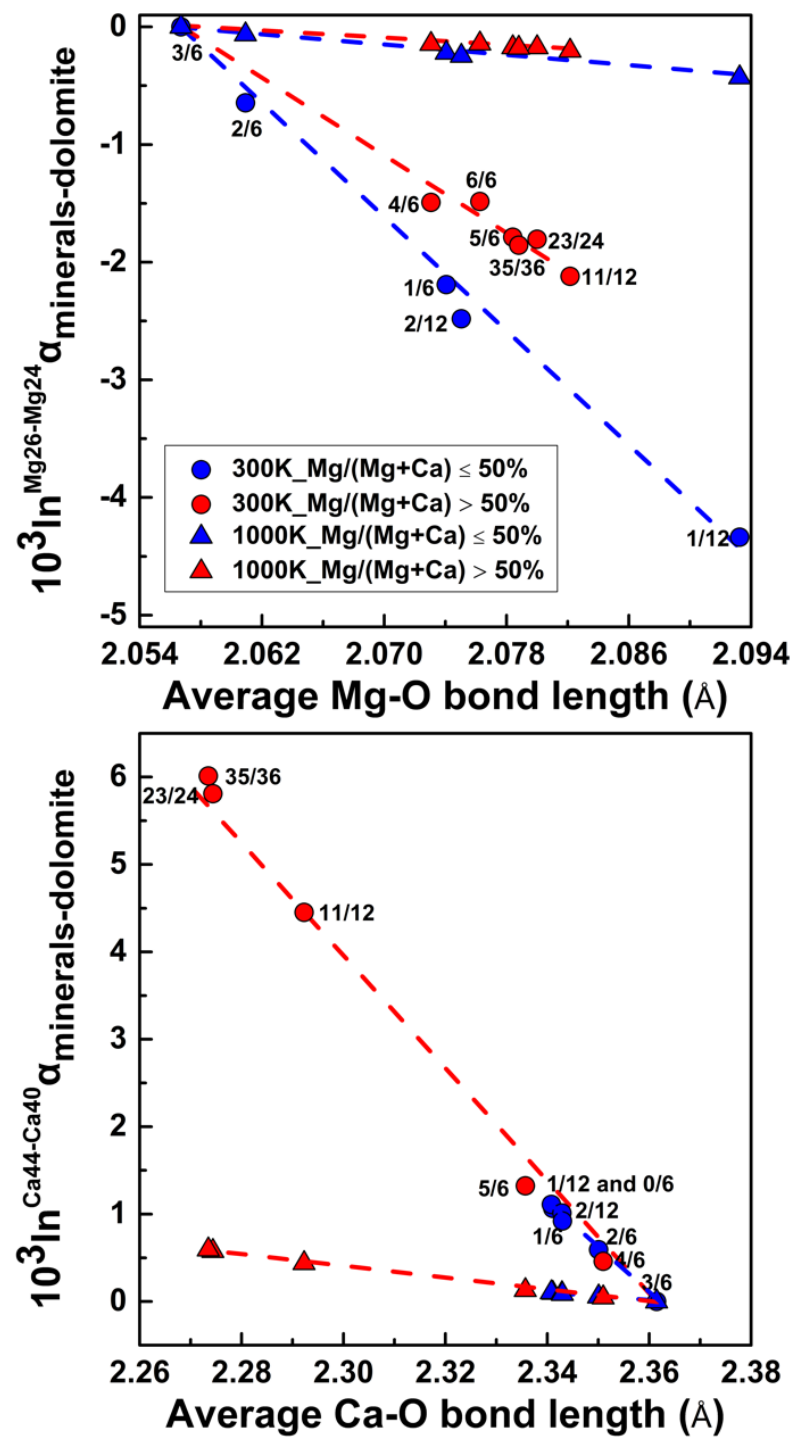

732

Figure 8. 